IZA DP No. 8203

Bouncing Back from Health Shocks:

Locus of Control, Labor Supply, and Mortality

Stefanie Schurer

May 2014 


\title{
Bouncing Back from Health Shocks: Locus of Control, Labor Supply, and Mortality
}

\author{
Stefanie Schurer \\ University of Sydney \\ and IZA \\ Discussion Paper No. 8203 \\ May 2014 \\ IZA \\ P.O. Box 7240 \\ 53072 Bonn \\ Germany \\ Phone: +49-228-3894-0 \\ Fax: +49-228-3894-180 \\ E-mail: iza@iza.org
}

\begin{abstract}
Any opinions expressed here are those of the author(s) and not those of IZA. Research published in this series may include views on policy, but the institute itself takes no institutional policy positions. The IZA research network is committed to the IZA Guiding Principles of Research Integrity.

The Institute for the Study of Labor (IZA) in Bonn is a local and virtual international research center and a place of communication between science, politics and business. IZA is an independent nonprofit organization supported by Deutsche Post Foundation. The center is associated with the University of Bonn and offers a stimulating research environment through its international network, workshops and conferences, data service, project support, research visits and doctoral program. IZA engages in (i) original and internationally competitive research in all fields of labor economics, (ii) development of policy concepts, and (iii) dissemination of research results and concepts to the interested public.
\end{abstract}

IZA Discussion Papers often represent preliminary work and are circulated to encourage discussion. Citation of such a paper should account for its provisional character. A revised version may be available directly from the author. 


\section{ABSTRACT \\ Bouncing Back from Health Shocks: Locus of Control, Labor Supply, and Mortality*}

Policy-makers worldwide are embarking on school programmes aimed at boosting students' resilience. One facet of resilience is a belief about cause and effect in life, locus of control. I test whether positive control beliefs work as a psychological buffer against health shocks in adulthood. To identify behavioural differences in labour supply, I focus on a selected group of full-time employed men of working age and similar health. Men with negative control beliefs, relative to men with positive beliefs, are $230-290 \%$ more likely to work part-time or drop out of the labour market after a health shock. In old age men with negative control beliefs are by a factor of 2.7 more likely to die after a health shock. The heterogeneous labour supply responses are also observed for other non-cognitive skills, but only for the ones which correlate with control beliefs. Interventions aimed at correcting inaccurate beliefs and negative perceptions may be a low-cost tool to moderate rising public expenditures on social protection and health care.

JEL Classification: $\quad$ I12, J24

Keywords: non-cognitive skills, locus of control, labor supply, mortality, health shocks, SOEP

Corresponding author:

Stefanie Schurer

School of Economics

University of Sydney

Room 370, Merewether Building

Sydney, NSW 2006

Australia

E-mail: stefanie.schurer@sydney.edu.au

\footnotetext{
* The author would like to thank Deborah Cobb-Clark, Paul Frijters, Dean Hyslop, and Wang Sheng Lee, Bob Slonim, and participants of seminars at University of Sydney and Monash University for valuable comments. All errors are my own.
} 


\section{Introduction}

Worldwide, policy-makers, media, and academics are debating the pedagogic secrets that make children successful (Tough, 2012). Participants in this debate suggest to complement traditional school curriculums with building character traits (e.g. Seligman et al., 2009). In fact, some economists have shown that childhood character traits, sometimes referred to as non-cognitive skills, are at least as important in determining life-time outcomes such as education, income, and health, as cognitive skills (Heckman et al., 2006).

Although economists and psychologists alike cannot agree on which character traits are the most relevant ones, one specific trait keeps on making headlines: Resilience. The concept emerged from the Positive Psychology literature (See Seligman, 2011) and captures an individual's ability to bounce back from setbacks. ${ }^{1}$ Unlike many other measures of personality, resilience captures several facets, and thus can be understood as a personality-package rather than a one-dimensional trait. ${ }^{2}$ An important component in this package is the belief that one can control the important outcomes of one's life, referred to as self-efficacy (Bandura, 1990), and the attribution of failure to oneself, referred to as locus of control (Rotter, 1966).

A series of studies has shown that individuals low on control beliefs tend to invest less in education (Coleman and Deleire, 2003; Hadsell, 2010) ${ }^{3}$, in health (Cobb-Clark et al., 2014; Chiteji, 2010), and in strategies to regain employment when faced with sudden job loss (Caliendo et al., 2014). If locus of control captures willingness to invest under threat, then it seems natural to hypothesise that individuals who believe they are in control of their destinies will manage severe setbacks better than individuals who do not.

\footnotetext{
${ }^{1}$ In addition to resilience, the positive psychology literature stresses the importance of positive emotions and purposeful meaning to life (e.g. Seligman et al., 2009).

${ }^{2}$ The concept of psychological resilience is defined as "the capacity to maintain, or regain, psychological well-being in the face of challenge. The definition underscores ... the capacity to flourish, develop, and function effectively despite difficult circumstances or events" (p. 12 Ryff et al., 2012).

${ }^{3}$ For evidence against this hypothesis, see Cebi (2007) and Duncan and Morgan (1981).
} 
I take this hypothesis to the test by studying individuals' responses to health shocks. Evidence of better adaptation skills to health shocks were observed for myocardial infarction survivors. Perceptions of personal control were linked with a better adherence to recommended medication and behavioral regimes and a higher rate of returning to work following the recuperative period (See Strudler Wallston and Wallston, 1978; Fitzgerald et al., 1993, for an overview of the literature). One mechanism that explains these heterogeneous responses is that positive beliefs about control is a proxy for the emotional ability to undercut feelings of hopelessness when faced with adversity (Thompson, 1981).

Whether affected individuals manage their illness recovery well will be measured by their decision to return to full-time work after a reasonable amount of time. Individuals who belief they are in charge of their destinies are expected to return faster to fulltime work than individuals who attribute the outcomes of their lives to others. To identify a causal effect of health on labour supply, I follow the standard literature by approximating exogenous variations in health with health shocks (See Smith, 2005, 1999; Currie and Madrian, 1999, for an overview). The underlying idea of this approach is that the experience of a health shock lies outside the influence of an individual's doing. Previous studies demonstrated that sudden changes in health induced retirement decisions or labour supply reductions for the older work population (Disney et al., 2006; Wing Han Au et al., 2005; Bound et al., 1999; Riphahn, 1999), forced younger individuals into inactivity (García-Gómez et al., 2010; García-Gómez and López-Nicolás, 2006), and that the employment effects may persist over many years (García-Gómez et al., 2013).

In the year of the health shock, it is likely that individuals both with positive (internals) and negative (externals) control beliefs will reduce their labour supply for treatment in hospital and rehabilitation. The question is: What happens in the year after? Who will go back to work, who will go part-time, or drop out all together? Is this decision 
related to a mere belief of control over destiny or are internals in general just healthier, experience weaker health shocks, or work in more flexible occupations that allow them to return to work at lower rates of recovery? ${ }^{4}$

The underlying mechanism that leads to heterogeneous labour-supply responses is simple: Internals are more inclined to invest in their health as a response to the shock, so that they recover faster, or that they perceive their health to be better after the investment. As a consequence, of course, in the long-run internals should be healthier, and therefore also have a longer life, than externals. The complex inter-relationship between health and beliefs makes clear that in order to show belief-related responses, one needs to control for the health-related responses.

To account for this complexity, I carefully construct an experiment within a highquality longitudinal data-set from Germany (German Socio-Economic Panel, SOEP). I pick a sample of initially 25 to 58 year-old men, measure their locus of control and health, and then follow their health and labour supply trajectories. Building on the strong evidence of the stability of various non-cognitive skills in adulthood, including locus of control (Cobb-Clark and Schurer, 2013, 2012), I have confidence that my measure of locus of control is not just a proxy for previous health or labour market experience. Similar to García-Gómez (2011) and García-Gómez and López-Nicolás (2006), I create intervals of three year-observations, and then analyse the medium-run effects of experiencing a health shock experienced in $t-1$ on labour-supply in period $t$. To ensure that the labour supply responses in period $t$ do not merely reflect a fixed propensity to work less that correlates with control beliefs, I condition the analysis on a sample of individuals who work full-time in period $t-2$. Selecting full-time working men for whom data is available for at least 11 years, I de facto prune the data to make the treatment (external control)

\footnotetext{
${ }^{4}$ Heckman et al. (2006) have shown that a youth measure of locus of control in combination with self-esteem explains a variety of adult economic outcomes including income, education, and health using data from the NLSY 79.
} 
and the control group (internal control) as comparable as possible in their initial health and labour supply.

I find strong and robust support for the hypothesis that externals reduce more strongly their labour supply a year after they have experienced a health shock. They are 230 percent more likely to work part-time than internals, and 290 percent more likely to drop out of the labour force. These effects remain when omitting the chronically ill, the "repeat offenders" (multiple shocks), and those dying over the sample period from the analysis. These effects also remain within groups of educational qualification, undermining the hypothesis that heterogeneous labour supply responses are due to externals working in low-skilled occupations with less flexibility. It is, however, also true that other character traits such as optimism, emotional stability, and conscientiousness have similar, buffering effects. This is so, because these traits correlate strongly with locus of control, suggesting that character traits cannot necessarily be understood as one dimension only. It is a package of traits: individuals who tend to believe they are in control of their destiny also tend to be more optimistic, and are less prone to mood swings (See also Judge et al., 2002). Finally, in a sample representative of all ages, very old external men are more likely to die after a health shock, which supports the hypothesis that at the end of life the cumulative effects of positive control beliefs manifest themselves.

The remainder of the paper is structured as follows: Section 2 outlines the theoretical framework that justifies the identification strategy, which is described in Section 3, which also explains the operationalisation locus of control, the health shock, the various measures of labour supply, and mortality. In Section 4, I will demonstrate graphically the dynamics of labour supply, health, and health care utilisation for individuals who experienced a health shock. The estimation results of various model specifications and robustness checks are presented in Section 6. Section 7 discusses the policy implications. 


\section{Theoretical framework}

Why would individuals with an internal locus of control reduce their work hours less as a response to a health shock than individuals with fatalistic beliefs? The following, brief theoretical framework and numerical example serve to demonstrate the potential pathways and motivates my identification strategy described in Section 3. To illustrate ideas, I build on Grossman's Health Investment Model (Grossman, 1972), which allows individuals to invest in their health to off-set a constant decline in health. The Grossman model embarks from an inter-temporal utility function and budget constraint. The total time available for work is determined by the individual's health status. The Grossman model can be solved for labour supply, and in the optimum labour supply will depend on heath status in time $t$, among other factors (See Schurer, 2008).

For simplicity, I loosely build on Schurer (2008)'s two-period model that introduced heterogeneity in the health investment function. This function links current health $\mathrm{H}_{2}$ with past investment $\left(I_{1}\right)$, past health $\left(H_{1}\right)$, and a depreciation rate $\delta(0<\delta<1)$. Investment enters the function non-linearly to emphasise that depreciation in health can directly be off-set by investment.

$$
H_{2}=\left(1-\frac{\delta}{I_{1}}\right) H_{1}
$$

Investment leads to higher objective or perceived health $\left(\frac{\partial H_{2}}{\partial I_{1}}>0\right)$. Individuals work less hours when they perceive their health to be too low to justify the effort to work (reductions in $H_{2}$ ), i.e. $\frac{\partial L S^{*}}{\partial H_{2}}>0$, where $L S^{*}$ stands for labour supply in the optimum. ${ }^{5}$

There are three hypotheses why internals are observed to reduce their labour supply

\footnotetext{
${ }^{5}$ It is immaterial for the analysis whether health status is objectively low or just perceived to be low. Individuals will decide over the hours they want to work on the basis of their perceived health, which may be imperfectly related to true health. Perceived health will affect the perceived disutility from work. For similar arguments in the context of malaria testing, perceived health and labour supply/productivity, see Dillon et al. (2014).
} 
less than externals after the experience of a health shock. All pathways work via differences in perceived or objective health. Let $\theta$ represent beliefs that are increasing in internal control. Investment is a function of locus of control $(I(\theta)$, Hypothesis 1$)$, internals experience smaller health shocks $(\delta(\theta)$, Hypothesis 2), or internals' initial health is better $\left(H_{1}(\theta)\right.$, Hypothesis 3$)$. I will demonstrate the consequences of each alternative hypothesis on labour supply with a numeral example. Let $\delta=0.5, H_{1}=100$ (\%), and $I_{1}=1$ (Unit). Under each scenario, the value of one of the three parameters will change.

\section{Hypothesis 1:}

Health investment increases with internal locus of control $\left(\frac{\partial I_{1}}{\partial \theta}>0\right)$, a hypothesis which finds wide support from the empirical literature. For instance, Cobb-Clark et al. (2014) have shown for Australian data that internal men follow a better diet and exercise more regularly, not because they are more efficient, but because they expect higher health returns in the future. Chiteji (2010) finds that internals exercise more for US data, but gives no explanations for why this is the case. In my setting, I understand health investments as the ability to adhere to strict treatment regimes, to maintain healthy habits such as being physically active or eating healthily, and to pursue non-standard treatment options that are not directly linked to primary and secondary health care (e.g. physiotherapy, spa visits, treatment at a health resorts). This reflect the notion of resilience: Internals will fight harder and try everything to overcome the problem. ${ }^{6}$ Let $I_{1}^{\text {Externals }}=1$ unit and $I_{1}^{\text {Internals }}=2$ units. Health levels for the two groups will vary as follows:

$$
H_{2}^{\text {Internals }}=\left(1-\frac{0.5}{2}\right) 100=75
$$

\footnotetext{
${ }^{6}$ Evidence of better adaptation skills to health shocks are reported among myocardial infarction survivors, perception of personal control was linked with a better adherence to recommended medication and behavioral regimes and a higher rate of returning to work following the recuperative period. Internal locus of control has been associated with knowledge about disease, ability to stop smoking, ability to lose weight, effective use of birth control, getting preventive inoculations, and getting regular dental checkups (See Strudler Wallston and Wallston, 1978; Fitzgerald et al., 1993, for an overview of the literature).
} 


$$
H_{2}^{\text {Externals }}=\left(1-\frac{0.5}{1}\right) 100=50
$$

As a consequence, internals will experience better (perceived) health in period 2, experience lower disutility of work, and will provide more hours of work than externals.

\section{Hypothesis 2:}

Instead of investing more in their health, internals experience smaller health depreciation despite starting out at the same level of initial health $\left(\frac{\partial \delta}{\partial \theta}<0\right)$, although there is little evidence in the literature to support this case. Let $\delta^{\text {Externals }}=0.5$ and $\delta^{\text {Internals }}=0.1$, which results in the following two health outcomes:

$$
\begin{aligned}
& H_{2}^{\text {Internals }}=\left(1-\frac{0.1}{1}\right) 100=90 \\
& H_{2}^{\text {Externals }}=\left(1-\frac{0.5}{1}\right) 100=50 .
\end{aligned}
$$

If internals experience weaker health shocks than externals, even in the presence of the same health investment and initial health level, internals will experience better health in time period 2. Yet again, better objective or perceived health results in lower disutility of work and thus internals will provide more hours of work than externals.

\section{Hypothesis 3:}

Internals start out with better health from the beginning such that $\frac{\partial H_{1}}{\partial \theta}>0$. There is ample evidence in the literature that internals rate their health better (e.g. Mackenbach et al., 2002; Klonowicz, 2001) In this third case, let $H_{1}^{\text {Internals }}=100$ and $H_{1}^{\text {Externals }}=50$. Health outcomes for the two groups are:

$$
H_{2}^{\text {Internals }}=\left(1-\frac{0.5}{1}\right) 100=50
$$




$$
H_{2}^{\text {Externals }}=\left(1-\frac{0.5}{1}\right) 50=25
$$

If internals started out with better health in period 1 , even in the presence of the same health investment, the same health shock, and a higher marginal drop in health for internals (50 vs. 25 units of health lost), internals will experience better health in time period 2. Yet again, better objective or perceived health results in lower disutility of work and thus internals will provide more hours of work than externals. Moreover, if internals have better health in period 1, then they will work more hours in period 1.

All three hypotheses lead to an observationally equivalent outcome. ${ }^{7}$ Therefore, it is important to choose an identification strategy that can separate out the heterogeneous labour supply response to health shocks from heterogeneity in initial health, in the intensity of a health shock, and in the histories of labour supply. This strategy will be explained in the next section. ${ }^{8}$

\section{Data, identification strategy, and variable definition}

\subsection{Identification strategy}

The data to carry out my analysis are taken from years 1994-2011 of the German SocioEconomic Panel (SOEP Data Release 1984-2011). The SOEP is a longitudinal survey of private households established in West Germany in 1984, which extended its sample

\footnotetext{
${ }^{7}$ Note, more complex scenarios can be thought of, e.g. that each of $\delta, I_{1}, H_{1}$ depend on $\theta$, or that $I_{1}(\delta)$. If internals are simultaneously investing more into their health in general, and in response to a health shock, and if they have better health, and experience weaker health shocks, then the health gap in period 2 between internals and externals will be even larger.

${ }^{8}$ It is worth explaining why my model does not express the same competing hypothesis that locus of control simply measures unobserved ability as discussed in Caliendo et al. (2014) and Coleman and Deleire (2003). In both studies, the alternative hypothesis is that for highly intelligent individuals jobs will arrive at a higher rate, and therefore highly able individuals are more likely to find a job. Unlike Coleman and Deleire (2003) and Caliendo et al. (2014) who model the heterogeneous behaviour of high school students and the unemployed, I focus on individuals who are full-time employed and hence do not apply for a (new) job. The only pathway where cognitive ability could play a role is that more able individuals are more efficient in transforming health investment into health, or that more able individuals work in jobs that require less physical work that facilitate the return to work. The former hypothesis was rejected by Cobb-Clark et al. (2014), while I test for the latter in a robustness check.
} 
after Germany's reunification to include the new Bundeslaender. ${ }^{9}$ In its first year the study included 5,921 households from which 12,245 individuals from age 17 onwards were successfully interviewed ("German West" and "Foreigner" sample). Further samples were added in consecutive years from which my study uses the "German East" (1990), "Immigrant" (1994/1995) and the "Refreshment" (1998) samples. The SOEP achieved a reasonably high first wave cross-sectional response rate of $64.5 \%$ and has an average longitudinal response rate of $92.2 \%$ (Wagner et al., 2006).

Figure A.1 in the Appendix describes which sample, years and variables are chosen to be able to separate out hypothesis 1 from hypotheses 2 and 3 . The main identification strategy relies on selecting a sample from the SOEP data for which locus of control and initial health are measured strictly before health changes and labour supply are measured (1994-1996), who experienced a health shock (between 1998 and 2010), and who look very similar in terms of their labour supply and health before the health shock. Starting in 1997, I draw from the data repeatedly three-year intervals which I use to condition the sample on individuals who are full-time employed (worked more than 37 hours) in the first year of the three-year interval $(t-2)$ and who experience a health shock in the second time period of the interval $(t-1)$. I then investigate in the third time period of the three-year interval $(t)$ whether individuals who do not return to full-time work, or drop-out from the labour market, are more likely to have fatalistic beliefs. In total, there are 13 three-year intervals (See Table A.1 in the Appendix). A similar strategy of three-year interval analysis is applied in García-Gómez (2011) and García-Gómez and López-Nicolás (2006).

Importantly, I consider the labour supply responses of men only, due to the difficulty in modelling female labour supply and separating out health shocks from child-bearing

\footnotetext{
${ }^{9}$ The data used in this paper was extracted from the SOEP Database provided by the DIW Berlin (http://www.diw.de/soep) using the Add-On package SOEP Info for Stata(R). It uses the 95\% Scientific sample obtained from Cornell University.
} 
years. The sample is further pruned to individuals who are no younger than 25 years and no older than 60 years of age at any point within the three-year intervals. The upper bound is chosen to ensure that short-term labour supply decisions are not driven by retirement decisions, which depend on superannuation availability and savings. The lower bound is chosen to ensure that short-term labour supply decisions are not driven by frequent transitions in-and-out of education.

An average measure of locus of control data is obtained from years 1994, 1995, and 1996. Similarly, an average measure of initial health is constructed from self-assessed health data also from years 1994, 1995, and 1996. As it is common in the literature to control for the effects of other non-cognitive skills and cognitive ability on labour supply, I further derive from the SOEP data measures of pessimism (1999), the Big-Five personality inventory $(2005,2009)$, risk attitudes (2005-2011), and a measure of cognitive test scores (2006).

In 1997, there are 4,623 individuals in the sample for whom full information is available on health and locus of control, and who are between 25 and 58 years of age. This sample is further reduced by 2,118 to $\mathrm{N}=2,505$, out of which 898 will experience a health shock at some point in time, when conditioning on non-missing information on all variables used in the estimation in Section 6. As a consequence of conditioning on individuals for whom data is available on e.g. all non-cognitive skills, a quarter of these individuals remains in the sample until 2011 ( $\mathrm{T}=14$ ), and on average individuals stay in the sample for 11 years. This implies that my sample is relatively homogeneous: full-time employed men, aged between 25-60, in good initial health, and for whom data is available across long stretches of the time interval.

Germany provides an ideal setting to test the medium-term responses to health shocks, because Germany's generous social security system ensures that almost everyone has 
universal access to health care and allows individuals to stop working, or reduce hours of work, when experiencing a debilitating illness while maintaining a regular income flow for at least $11 / 2$ years thereafter. In the case of illness, German employees can rely on income provided by various insurance funds. ${ }^{10}$ The sickness funds give cash benefits to sick insured during the first six weeks of sickness while employers pay $100 \%$ of the employee's last net income. Afterwards, sickness funds continue to pay for up to 78 weeks $80 \%$ of the last net income (Johnson and Stoskopf, 2010).

In addition, medical health care is universally provided independent of employment status, unlike the United States, where health insurance is mainly tied to the employer. The latter implies that individuals may have to continue to work in case of illness, just to be able to afford health care (Bradley et al., 2007). Further, even though the German Termination Protection Act allows employers to lay off employees who are on long-term sick leave, they must abide with strict notice periods of seven months. To this extent, short-term changes in employment due to illness-related layoff are unlikely to be observed in the time-frame of this analysis. This means that one can study the short-term effects of deteriorations in health on labor supply as a result of individual choice rather than being the result of a budget constraint or health related lay-off.

\subsection{Variable definitions}

\subsubsection{Locus of control}

In 1994, 1995, and 1996, the SOEP included a personality questionnaire that contains eight of the original 23-items of the Locus of Control Scale developed by Rotter (1966). The scale assesses the extent to which one regards opportunities in life as being under one's control (internal locus of control) versus being chance-determined, incidental, and

\footnotetext{
${ }^{10}$ The German Social Security System consists of health insurance, home care and nursing insurance, pension insurance and unemployment insurance and it is mandatory to all employees.
} 
unpredictable (external locus of control). Participants were asked to indicate their agreement with each of the eight items on a scale ranging from 1 (applies completely) to 4 (does not apply). The answers to items Q1, Q3, and Q6 were reversed so that high values of each item indicate external control tendencies (See Table 1 for definitions).

An explanatory factor analysis reveals that all eight items load unambiguously on one principal factor (see screeplot in Fig. A.2 in the Appendix). However, I dropped item Q3 from the overall inventory as the internal consistency as measured by Cronbach's $\alpha$ (Cronbach, 1951) can be improved to 0.7454 (versus 0.7388 ). ${ }^{11}$

To achieve higher construct validity, I predict the first principal factor from a principal component analysis. ${ }^{12}$ Using a predicted first factor as index of external control instead of a measure that sums all items allows for each item to enter the index with a different weight (e.g. Piatek and Pinger, 2010, who use the same strategy and data). Once the first principal factor is predicted in each of the three years 1994-1996, I average for each individual the constructed index across these years. Averaging across repeated measures reduces the likely measurement error in self-assessed non-cognitive skills. Using both factor analysis and an average measure over repeat observations reduces noise in the data (see Cobb-Clark and Schurer, 2013, for the arguments and similar strategies). ${ }^{13}$

\footnotetext{
${ }^{11}$ Cronbach's $\alpha$ measures how closely related are the eight items as a group by considering the proportion of the average inter-item covariance in the total variation in the data. Higher levels of $\alpha$ are usually an indicator for one underlying concept. A level of 0.7 or above is usually accepted as satisfactory. Heineck and Anger (2010) also use SOEP data and calculate Cronbach $\alpha$ reliability measures for, among others, locus of control data measured in 2005. They exclude Q1, Q4, Q6, and Q7, however, a principal component analysis of Q2, Q3, Q5, Q8, Q9, and Q10 yields two factors upon which all remaining questions load and the resulting Cronbach's $\alpha$ is .62, which is significantly lower than the Cronbach's $\alpha$ obtained when excluding Q4, Q6, and Q9.

${ }^{12}$ Similar definitions have been used elsewhere (e.g. Cobb-Clark et al., 2014) or compared its performance against constructing a summed measure (e.g. Cobb-Clark and Schurer, 2013) that has been used in e.g. Caliendo et al. (2014). The method to aggregate the locus of control measure do not affect the estimation results.

${ }^{13}$ Cunha and Heckman (2008) and Cunha et al. (2010) emphasise the importance of measurement error in non-cognitive skills in their analysis of the determinants and the evolution of non-cognitive skills in early childhood and adolescence. To deal with measurement error and simultaneity, they develop a dynamic latent factor structural equation model. Identification is achieved through maintained assumptions regarding (i) the production function and (ii) the variance-covariance matrix for the individual items in the measurement model.
} 
A binary measure of external control tendencies, that will be used in some of the descriptive and mortality analysis, is defined to take the value 1 if the index is greater than the $75^{t h}$ percentile and 0 if it is smaller or equal to the $75^{\text {th }}$ percentile. The $75^{\text {th }}$ percentile cut-off value takes into account the left-skewed nature of external control tendencies. ${ }^{14}$

Should we be worried about the potential endogeneity in locus of control to experiencing health shocks and labour market experience? Cobb-Clark and Schurer (2013) investigated in detail whether locus of control, and also Big-Five personality measures (Cobb-Clark and Schurer, 2012), respond to unanticipated life events. They conclude that for a working age population (25-60) measures of no-cognitive skills are surprisingly stable. Individuals do not reverse their control tendencies, even when exposed to a series of labour market, health, and family-related life events. At best, individuals change their answers by three points on a scale from 7 to 49. These small changes cannot be explained by life events, and are considered noise. ${ }^{15}$

It is further possible that locus of control as measured in 1994-1996 is the result of prior normative, i.e. age-specific, variations. In a robustness check, I adjusted locus of control scores by age (e.g. Heineck and Anger, 2010). None of my conclusions change by using the age-adjusted measure, likely because in my sample locus of control does not co-vary substantially by age (See Table A.5 in the Appendix). These results are provided upon request.

\footnotetext{
${ }^{14}$ There is no generally accepted threshold to categorize individuals into internals and externals. Caliendo et al. (2014) use the sample mean as a cut-off value.

${ }^{15}$ Psychologists have devoted a great deal of effort to understanding the development of locus of control tendencies, especially during childhood (see Weisz and Stipek, 1982, for a review), but little conclusive evidence exists on their malleability in adulthood. While Gottschalk (2005) finds for a sample of long-term unemployed that an exogenous increase in work hours increased internal control tendencies, Goldsmith et al. (1996), using data from the National Longitudinal Survey of Youth (NLSY), finds very modest evidence that longer spells of unemployment could lead to the development of external control tendencies. My sample conditions on individuals who are in full-time work and thus differ from the sample of Gottschalk (2005) and Goldsmith et al. (1996).
} 


\subsubsection{Health shocks}

To assess the effect of health on labor supply, it is common in the literature to use a binary measure of a health shock. Smith (1999) and Smith (2005) argue that unanticipated, or at least significantly large, changes in health could serve as an exogenous change in health that aids identification of a causal impact of health on labor supply. I will follow this method, but instead of constructing the health shock from self-assessed health data, ${ }^{16}$ I exploit extreme changes in health care utilisation data, namely from nights spent at hospitals and doctor visits, that indicate acute health problems.

In Germany, as in many OECD countries, patients have little influence over the number of nights spent in hospital to treat a health condition, especially since the introduction of Diagnosis-related groups (DRGs)-type payment system in 2000, which classifies patients into groups according to the consumption of resources required to their condition. Acute hospitalisations have been used to measure health shocks e.g. in García-Gómez et al. (2013). One could argue, however, that the number of doctor visits does not measure acuteness, but preventive care, and is therefore a proxy for health investments that may differ by locus of control. In Section 4, I show that internals and externals do not differ in their number of doctor visits at any time before, after and during a health shock, concluding that my health shock definition is not misleading. Moreover, in a robustness check I can demonstrate that my conclusions hold firmly even when defining the health shock via self-assessed health or nights spent in hospital only.

\footnotetext{
${ }^{16}$ E.g. Riphahn (1999), García-Gómez (2011), and García-Gómez and López-Nicolás (2006) construct a health shock from subjective health data, which will be considered in a sensitivity analysis. However, it is not the preferred solution in my setting to use self-assessed health for the construction of the health shock, because large variations in self-reports of health have been linked to variations in the personality trait of locus of control (Klonowicz, 2001). In such a case, more externally controlled individuals would report a health shock despite having the same 'objective' level of health as internally controlled individuals and thus would not be more likely to change their labor supply than a comparable internally controlled individual. An optimal health shock measure would be a purged health measure, which is the predicted value from an estimated model of self-assessed health that controls for specific medical conditions (e.g. Bound et al., 1999; Disney et al., 2006; García-Gómez et al., 2010), which is not available in SOEP.
} 
To construct the health shock measure, I sum for each individual in each year the Total number of nights spent at hospital and the Total number of doctor visits and then take a first difference. As described in (8), an individual is considered as having experienced an unusual deterioration in health when the increase in total number of health care visits from one year to another is greater than one standard deviation in the sample $\left(\sigma_{H}\right)$, or 21 visits/nights (from here onward referred to as health care visits):

$$
H S_{i t}=1 \text { if } \delta_{i t}=H_{i t}-H_{i t-1}>\sigma_{H},=0 \text { otherwise. }
$$

Data from the European Community Household Panel (1996) reveal that on average Germans consult a GP five times, a specialist three times, and spend two nights in hospital per year (Van Doorslaer and Masseria, 2004), which sums on average to ten visits per year. My measure of a health shock implies at least 11 extra doctor visits/nights spent in hospital in comparison to the German average.

Figure 3(a) in the Appendix describes the distribution of changes in health care visits. The largest change observed in the data is 515 extra visits, but only a small proportion of the sample have more than 42 extra health care visits in comparison to the year before. In total, $5 \%$ of the sample experience changes in health care visits greater than 21 visits. Figures 3(b) and 3(c) plot the changes in nights spent in hospital and self-assessed health. Individuals with more than 17 nights spent at hospital (1 SD, $1.5 \%$ of sample) or who drop their self-assessed health by more than 2 units (4 SD, $2.9 \%$ of sample) since the previous time period, are considered to experience a health shock. The maximum change in hospital nights in the sample is 300 more nights, while the maximum drop in selfassessed health is four.

To further investigate what health conditions this measure captures, I exploit for a sub-sample of individuals data on health diagnosis that is available in the SOEP in 2009 
and 2011. Table A.2 reports the marginal probability effects from regressing a health shock indicator on age, locus of control and ten indicators for diagnosed health conditions in the year of the health shock. Having been diagnosed with cancer is by far the strongest predictor of the health shock (7.4 percentage points), followed by psychiatric depression (4.9 percentage points), stroke (3.2 percentage points) and diabetes (3 percentage points). Relative to the sample mean of experiencing a health shock (5.8 percent), these marginal probability effects (MPE) imply an increase in the probability of a health shock in the magnitude of $127 \%, 85 \%, 55 \%$, and $52 \%$, respectively. Locus of control does not correlate with the probability of experiencing a health shock ( 0.2 percentage points, not significant), not even when removing all objective health indicators (MPE: -0.0004, SE 0.0042), or when using the full estimation sample (MPE: 0.025, SE 0.021).

Further evidence on what type of illnesses or health threats underlie my health shock metric comes from data on German in-patient length-of-stay by diagnosis provided by the European Commission and OECD. Diseases of the circulatory system require ten days, of the respiratory system require less than nine days, of the muskoskeletal system and connective tissue require 11 days, lung cancer 12 days, and breast cancer eight days spent in hospital per year. More severe conditions entail longer times spent at hospital, though. For instance, obstructive pulmonary disease entails 120 days, acute myocardial infarction 105 days, asthma 80 days, cerebrovascular disease 270 days. $^{17}$

Therefore, when defining the health shocks via extra nights spent at hospital $(>17$ nights), then at a minimum I pick up various cancer treatments and at a maximum heart attacks and stroke, if these patients are still available for interview in this particular year.

\footnotetext{
${ }^{17}$ Data collected between 1998 and 2000 are accessible at: www.ec.europa.eu/health/ ph_information/dissemination/echi/echi_4_en.htm\#37 and www.euphix.org/object_document/ o5579n27121.html.
} 


\subsubsection{Labour supply}

To measure labour supply, I construct a binary measure that represents part-time employment or dropping out from the labour market. Part-time employment takes the value 1 if the individual works less than 20 hours per week (including zero hours), which affects $8.1 \%$ of the sample. This is an arbitrary cut-off, but in Germany there is no uniform definition of part-time work. An employee is considered to be part-time employed if his or her weekly working hours fall short of the fixed working hours arrangement of the particular industry and business. For instance, if the fixed working hours arrangement is 38.5 hours per week, then someone working 35 hours per week is considered to be working part-time. ${ }^{18}$

According to the Working Hours Legislation (Paragraph 3 ArbZG), the upper limit of work-hours is eight hours per day, hence someone who works 20 hours per week or less could work at maximum $21 / 2$ days during the week. For simplicity, however, the measure will be referred to as part-time work. Alternatively, I explore a cut-off value of 35 hours, which is the official part-time definition in e.g. Australia (12.1\% of sample).

In addition, I create a binary indicator for the probability of dropping out of the labour market (stop searching for a job, $1.7 \%$ of sample) and the probability of being officially registered as unemployed (3.9\% of sample), and therefore seeking work.

\section{Descriptive analysis}

Below, I demonstrate what is happening to the selected sample of individuals before and after they experience a health shock $(t-1)$, starting two periods before the shock $(t-2, t-3)$ until three periods after the shock $(t, t+1, t+2)$. The evolution of work hours, number of doctor visits, nights spent at hospital, total health care visits, and self-

\footnotetext{
${ }^{18}$ In a robustness check I have also considered a continuous measure of work hours. The conclusions from the main analysis hold even for this continuous measure. Results are provided upon request.
} 
assessed health is depicted both for internals $(<=75$ th percentile) and externals $(>75$ th percentile). As the sample is conditioned on working more than 37 hours in period $t-2$, there are barely any differences in the levels of work-hours by locus of control (Figure 1(a)). Internals work 45.5 hours per week while externals work 44 hours per week, with $95 \%$ confidence intervals almost overlapping. In period $t-3$ no significant differences are present. In the year of the health shock, as expected, hours of work drop markedly for both groups, but more so for externals than for internals. This gap keeps on widening over the next three time periods $(t, t+1, t+2)$, which emphasises that individuals with external control tendencies react more extreme than internals.

However, at no point in time do internals consult a GP or specialist more often then externals (Figure 1(b)). In the two time periods leading to the health shock, both internals and externals see a doctor about 10 times a year. In the year of the health shock both groups see a doctor about 42 times, while in the three time periods for both groups equally the number of doctor visits declines to 15-18. Similarly, the number of nights spent at hospital for both internals and externals is the same leading up to the health shock (about 1-2 nights) and after the health shock (overlapping 95\% confidence intervals). However, during the health shock, the number of nights spent at hospital is substantially higher for externals (13 nights) than for internals ( 8 nights). This implies that the health shock is stronger for externals than for internals, not only at the mean of the levels (Figure 1(c)), but also in the middle of the distribution of increases in health care visits (40-90 extra visits) (Figure A.5 in the Appendix). No difference though is observed in the right hand side of the distribution of changes in health care visits.

Last, internals and externals do not differ in their self-assessed health in both time periods leading up to the health shock (Figure 1(e)) (overlapping 95\% confidence intervals), and only marginally differ in their health assessments during the health shock ( $\mathrm{t}-1)$, while 
internals report an average health status of 3.3 and externals report an average health status of 3.5 (Health status is decreasing on this scale). Health status is still different one time period after the health shock, but then converges in period $t+1$. Pre-health shock health between the two groups is even more alike in the robustness check sample.

The observation that nights spent at hospital are larger and self-reported health is worse for external individuals that underlie the health shock stresses the importance of controlling for these potential factors and will be addressed in the model specification and robustness checks outlined in Section 5 .

\section{Estimation strategy}

\subsection{Modelling labour supply}

To estimate the buffering effects of locus of control, I rely on the following labour supply specification, with a focus on working part-time or zero hours. ${ }^{19}$ Let $P T_{i t}^{*}$ be the true, but unobserved willingness to work part-time or drop out of the labour market:

$P T_{i t}^{*}=\alpha_{0}+\alpha_{1} L \bar{O} C_{i}+\alpha_{2} H S_{i t-1}+\alpha_{3} L \bar{O} C_{i} \times H S_{i t-1}+X_{i t}^{\prime} \beta+Z_{i t-2}^{\prime} \phi+\gamma \bar{H}_{i}+N C S_{i}^{\prime} \mu+\varepsilon_{i t}$.

In the data a binary measure $P T_{i t}$ is observed which takes the value 1 if the willingness to work part-time is $P T_{i t}^{*}>0$, and 0 otherwise. The parameter $\alpha$ is the average probability of working part-time in the sample and $\alpha_{1}$ represents the deviation from this mean by external locus of control $\left(L \bar{O} C_{i}\right)$.

The variable $H S_{i t-1}$ is a binary indicator of extreme health depreciation, lagged by one time-period to ensure that changes in health are not the result of contemporaneous work conditions. Importantly, the health shock enters the equation also as an interaction

\footnotetext{
${ }^{19}$ In the empirical section, I will also estimate the probability of being registered as unemployed and dropping out of the labour market.
} 
with the continuous measure of locus of control $\left(L \bar{O} C_{i} \times H S_{i t-1}\right)$. The model further includes a proxy for the health history of the individual $\bar{H}_{i}$ that is measured as the average of self-reported health status between 1994 and 1996, strictly before labour supply and health changes were measured.

$X_{i t}^{\prime}$ is a vector of personal characteristics (age groups in five year intervals starting at 25-29 year old up until 55-60 year old, education, marital status, being a foreigner, children) and current economic conditions (state unemployment rates ${ }^{20}$, state fixed effects, and time fixed effects) affecting contemporaneously the probability of working part-time. $Z_{i t-2}^{\prime}$ is a vector of variables that proxy the individual's productivity potential, life-time earnings and benefit entitlements when employed (cumulative part-time experience since working, prior wage, size of firm, occupational status, industry, and tenure and tenure squared at firm of employment). ${ }^{21}$ Finally, $N C S_{i}^{\prime}$ is a vector of other non-cognitive and cognitive skills that are likely to influence labour supply decisions such as the Big-Five personality traits (Agreeableness, Conscientiousness, Extraversion, Neuroticism, Openness to Experience), pessimism, willingness to take risks, and a measure of cognitive ability (Symbol digits modality tests). I followed Heineck and Anger (2010) to chose the same variables of cognitive and non-cognitive skills.

A description of all control variables for this base-line model and their summary statistics by locus of control tendencies are provided in Table A.3 in the Appendix.

The error term $\varepsilon_{i t}$ is assumed to be normally distributed with a 0 mean and a variance of 1 (binary probit). Due to repeated observations across time, the standard errors are clustered by individual identifiers. By assuming that $L \bar{O} C_{i}$ and $N C S_{i}^{\prime}$ pick up all relevant

\footnotetext{
${ }^{20}$ Data on local unemployment rates are taken from the German Labor Agency Statistics and merged to the SOEP data on the basis of state and year identifier. These data are accessible at: http://www . pub.arbeitsamt.de/hst/services/statistik/detail/z.html.

${ }^{21}$ These measures are noisy proxies of what Blundell and MaCurdy (1999) stress should be included in labor supply models such as life-time wages, non-labor income (property income), and initial wealth. The authors admit that usually these are not included in survey data or measured with error. However, in my empirical specification, main interest is not to estimate consistently wage elasticities, but the effect of health and locus of control. My model specification is closely linked to Riphahn (1999).
} 
individual-specific heterogeneity that correlates with changes in health, conditioning on cumulative experience of part-time work and initial health, and under the assumption that the functional form is correctly specified, then the parameters of interest can be consistently estimated with Maximum Likelihood.

The main hypothesis of interest is $H_{0}: \alpha_{3}=0$ and $H_{a}: \alpha_{3}>0$, but the coefficients representing the interaction effects in a non-linear setting are not straight forward to interpret. Therefore, I will construct marginal probability effects, and use the delta method to calculate standard errors. Marginal probability effects for interaction effects are calculated as suggested in Karaca-Mandic et al. (2012). The interaction effect of locus of control and the health shock on labour supply is expressed as a movement from the lowest $10^{\text {th }}$ percentile of locus of control (being internal) to the highest $10^{\text {th }}$ percentile (being external), which is a common way used in the literature to represent the effects of non-cognitive skills on an outcome of interest (e.g. Heckman et al., 2006).

The above specified model is preferred over a specification without interaction term between locus of control and the health shock according to both AIC, and McFadden's R-squared criteria for part-time work and inactivity as outcome measures. It passes both a goodness-of-fit test (Hosmer-Lemeshow) and a functional form test (Pregibon's Link) at $5 \%$ level of significance or better (See Table 2, bottom).

\subsection{Pathways and Robustness checks}

To understand better the pathways via which the interaction effect of locus of control with health shocks operate, I repeat the same analysis by education. Germany's threetier education system separates students at age 10 into university school pathways, which is often blamed for creating an education system that allows for little upward mobility (See Heineck and Riphahn, 2009, for an overview). Children who go through the minimum schooling pathway (Hauptschule) will end up mainly in manual labour profession, 
whereas individuals going through the intermediate schooling pathway, select into administrative, low-level public sector, and service occupations, although some can go on to obtain a degree from a polytechnic university. Students who go through the highest level of schooling (Gymnasium) usually go on to university and take managerial, professional or technical occupations. If the buffering effects of locus of control reflect a general principle, and not just an occupational-specific phenomenon, then we should still observe the buffering effects of locus of control within each education group.

Further, a series of robustness checks will be conducted: (1) Use a different health shock measure (nights spent at hospital, self-assessed health) and (2) a different cut-off value for part-time work ( $<35$ hours), (3) Drop individuals who chronically suffer from health conditions (Health care utilisation in period t-1 > mean $=4$.), (4) Drop individuals who experience more than 2 health shocks across the sample period $(\mathrm{N}=42)$, and (5) Drop or recode labour supply response of individuals who died $(\mathrm{N}=9)$. Robustness check (35) aim at controlling for the possibility that the interaction effect of locus of control and health shocks is driven by initial differences in health, chronic health problems, or more extreme health shocks that are also linked to locus of control. For instance, Figure A.4 shows those 42 individuals who experience 3,4 or 5 health shocks are slightly more external than individuals who experience 1 or 2 shocks only.

Last, I will investigate whether other non-cognitive skills are just as likely to act as a buffer to health shocks. Therefore, I conduct a placebo test, in which I interact the health shock iteratively with any of the above described non-cognitive skills.

\subsection{Modelling the probability of dying}

To model the probability of dying, I use the full sample available (age 17 to 97 ), as only 9 individuals die in my pruned sample described in Section 3. In the full sam- 
ple $(\mathrm{NT}=53,529)$, there are 479 individuals who died $(9.4 \%) \cdot{ }^{22}$ Kaplan-Meier bivariate analysis is used to graphically depict the hazard functions by locus of control. Cox proportional hazard regression is used to estimate the probability of dying by age-groups, while controlling for age, being married, permanent health, level of education, locus of control, health shocks, and an interaction of the health shock with locus of control.

The regression model passes a test of the proportionality of the variables included in the analysis. All results will be reported in terms of hazard ratios, which is a ratio of two odds ratios. ${ }^{23}$ For simplicity, the measure of locus of control is a binary indicator (external versus internal control tendencies) as described in Section 3.2. It needs to be stressed that this analysis is a test for whether negative control beliefs, cumulatively over the life cycle, are associated with earlier death after a health shock. Due to the sample size restrictions I cannot match the treatment and control group in a similar way as in the labour supply responses.

\section{Estimation results}

\subsection{Labour supply and locus of control}

\subsubsection{Main specification}

Table 2 reports the marginal probability effects (MPE) of selected variables on working part-time (including zero hours), dropping out of the labour market, and being registered unemployed. Coefficients from the full model are reported in Table A.4 in the Appendix. The difference in the effect of a health shock for an individual at the lower end of the locus of control distribution (internals) and individuals at the higher end of the distribution (externals) is 0.067 with a standard error of 0.026 . This means that externals who

\footnotetext{
${ }^{22}$ The mortality rate in my sample is in line with the $9 \%$ reported in Frijters et al. (2011), who use the same data up until 2009, but a more sophisticated method to estimate the effect of latent, unmeasurable health shocks on mortality.

${ }^{23}$ The empirical specification of hazard rates is closely aligned with Bruin (2011).
} 
experienced a health shock in period $t-1$ and who were full time employed ( $>37$ hours of work per week) are 6.7 percentage points more likely to work part-time (or drop-out) a year after the health shock than internals with the same experience. Relative to the sample mean, this implies a $228 \%$ increase in the probability of working part-time.

A similar difference between internals and externals is found for the probability to drop out of the labour force (4.9 percentage points with a standard error of 1.3). Relative to the sample mean, external men are $288 \%$ more likely to drop out of the labour market than internal men after experiencing a health shock. In contrast, differences in the response to a health shock do not occur for unemployment (MPE -0.011; SE 0.018).

The heterogeneous response is sizeable in comparison to the MPE of other variables. For instance, older individuals (55-60 years) are 8.8 percentage points more likely to work part-time than young individuals (25-29), doubling the hourly wage in period $t-2$ is associated with a 4.4 percentage point drop, and an increase in the local unemployment rate by one-standard deviation is associated with a 1.2 percentage point increase in this probability. Individuals at the higher end of the tenure-at-firm distribution are 1.2 percentage points less likely to become part-time than individuals at the lower end.

The level effects of education and some other non-cognitive skills on the probability of working part-time are sizeable too: A one-standard deviation increase in years of education or conscientiousness reduces the probability by 1.1 percentage points, and a one-standard deviation increase in neuroticism or pessimism has the opposite effect. There are no level effects for cognitive ability, agreeableness, openness, and extraversion.

\subsubsection{Robustness checks to main specification}

The results of the previous section demonstrated that the buffering effects of locus of control with respect to labour supply are sizeable. They continue to persist when changing the health shock or part-time definition, or when further pruning the sample to make 
externals and internals more comparable in terms of their health status or the intensity of the health shock. These checks are reported as box-plots in Figure 2, where the black dot represents the MPE and the capped lines represent $95 \%$ confidence intervals. All MPE in the robustness checks are significant at the $5 \%$ level, except for the MPE on self-assessed health, which is significant at the $10 \%$ level.

The MPE of the interaction of locus of control with the health shock is still 5 percentage points when using a part-time measure of working less than 35 hours or self-assessed health to construct the health shock. The treatment effect grows to 8.8 percentage points when using number of hospital nights only to create the health shock. When dropping all individuals who experience more than twice a health shock in my sample or who have a chronically high demand for health care, the MPE remains at over 5 percentage points. Finally, dropping all individuals who died, or setting their labour market outcome equal to dropping out, if they died after they experienced a health shock, does not change the treatment effect. Hence, I have certainty that the buffering effect of locus of control is at a minimum 5 and at a maximum 9 percentage points.

\subsubsection{Placebo test}

Finally, I test whether internal locus of control is just a good proxy for any other noncognitive skill. Figure 3 graphically depicts the MPEs for seven alternative interactions effects. Being pessimistic or highly neurotic has equally, or even more, negative effects as external control tendencies on labour supply after the experience of a health shock, and being risk-loving or conscientious has equally strong, but opposite effects. However, extraversion, openness to experience, and agreeableness do not matter.

Why would other traits have similar buffering effects as locus of control? One explanation is that external locus of control correlates strongly with pessimism, risk-aversion, and neuroticism (See Table A.5 in the Appendix), but does not correlate with agreeable- 
ness, and correlates only weakly with extraversion (See also Schwarzer and Warner, 2013; Almlund et al., 2011; Judge et al., 2002). These correlations suggest that it is difficult to separate the effects of locus of control from the effects of pessimism or neuroticism. Judge et al. (2002) suggests that self-efficacy, neuroticism, and self-esteem are all part of the same construct which is refereed to as self-evaluations. Neuroticism is linked with depressive symptoms, which strongly affects how gloomy and pessimistically individuals perceive the world around them. Many of the locus of control questions have a pessimistic or a gloomy air in them (e.g. "No one can escape their own destiny", "something unforeseen always happens").

However, internal control tendencies do not correlate with conscientiousness in our sample and yet, conscientiousness exhibit similar buffering effects to health shocks than does internal locus of control. One explanation is that conscientious individuals are very dependable and follow protocols. This will help them to follow treatment regimes carefully and the advice from their doctors. Such evidence has been reported in the literature in non-clinical populations, but the evidence is mixed in clinical populations (See Christensen and Johnson, 2002, for an overview). Other studies found that conscientiousness is associated with a range of other health-relevant beliefs, such as locus of control, optimism, life purpose, and self-faith (Marshall et al., 2014) and with active problem-focused coping behavior (Watson and Hubbard, 1996).

The main conclusion to draw from the alternative interaction effects is to understand external locus of control as a package of traits, that includes notions of pessimism, gloomy perceptions, increased levels of risk aversion, and possibly low levels of conscientiousness, that, in combination, make individuals less well equipped to respond to health shocks. 


\subsubsection{Pathways of the buffering effect of locus of control}

Figures 4(a) and 4(b) show the predicted probabilities of part-time work, for a sample who experienced a health shock and who were full-time employed before the health shock occurred, across the entire distribution of locus of control and education, respectively. Both graphs illustrate for this self-selected sample of 898 observations that both education and external control tendencies have the same buffering effect, just in opposite directions. Is locus of control just picking up the effect of education, or skill-related occupations, given especially that locus of control correlates strongly with years of education (See Table A.5)? If yes, then we should find no longer a buffering effect of internal locus of control within each education group.

Figure 4(c) displays the predicted probabilities of part-time work across the locus of control distribution separately for individuals who dropped out of school or finished minimum schooling (solid line), individuals who finished an intermediate school degree (long-dashed line), and individuals who pursued a higher education school pathway (dotted line). The buffering effect of locus of control is still present in each education pathway, but to differing degrees. The strongest effect of locus of control is for individuals in the intermediate school pathway, whereby externals are 15 percentage points more likely to work part-time than internals after the experience of a health shock.

For individuals with the lowest school credentials, the difference between internals and externals is approximately 10 percentage points, while for individuals in the highest educational school path the difference is roughly 7 percentage points. The effect may be largest for the intermediate group members because they are most likely to work in low-level civil service posts with a high degree of social protection. 


\subsection{Mortality and locus of control}

If it is true that individuals with external beliefs recover less from health shocks and experience them more often, then it should also be true that over they life-cycle they are more likely to die earlier than individuals with internal control tendencies. It is then also more likely that externals will die after a health shock than externals. These questions are assessed by using a sample of all individuals aged between 17 and 97 between 1997 and 2011, in which 479 individuals will die over an interval of 15 years.

Figure 5 depicts Kaplan-Meier survival functions for both externals (light grey) and internals (dark grey). At any point in time after 1997, externals have a higher risk of dying than internals (lower survival estimate). The bivariate differences are statistically significant at the $1 \%$ level. However, the significant difference between internals and externals disappears when controlling for age, education, marital status, health shocks (interacted with locus of control), and initial health status.

Table 3 reports the hazard ratios (ratio of odd ratios) of the probability of dying (Column 1). A standard deviation decrease in health in 1994-1996 increases the hazard ratio by a factor of 1.5 , and the experience of a health shock increases the hazard ratio by a factor of 2.5. An extra year of education reduces the hazard of dying, and so does being married.

Individuals with external control tendencies are by a factor of 1.3 more likely to die after a health shock than internals who experience a health shock, but the effect is not statistically significant at standard levels. However, among the elderly in my sample (> 70 years), the interaction effect between health shocks and external control tendencies is statistical significant at the $5 \%$ level. Externals who are experiencing a health shock after they turned 70, are more likely to die by a factor of 2.7 than internals. Although there are only 20 individuals in the sample who are external, who experienced a health shock, 
and who died afterwards, the findings are consistent with the hypothesis that externals, over the life cycle, recover less from health shocks, and cumulatively, this will make them more vulnerable when experiencing a health shock at the end of their life.

\section{Discussion}

In this study, I find strong and robust evidence that individuals who believe that they are in control of their life (internals), independent of whether this is true, are able to better weather adverse health shocks than individuals who attribute the important outcomes of their lives to chance (externals). Internals are more likely to return to full-time work than externals and are less likely to die from a health shock in very old age. These findings imply both that beliefs of control are no illusions of control, and that locus of control, as measured in the German Socio-Economic Panel, approximates well what the positive psychology literature would call resilience (Seligman, 2011).

However, it is difficult to separately identify the adversity-defying effects of locus of control from other adversity-defying traits such as optimism, emotional stability, and conscientiousness. All of these traits describe equally well the heterogeneity in labour supply response, but one should not consider this ambiguity as a weakness of this study. Locus of control is just one component in the complex system of human beliefs and perceptions; it overlaps with other, but certainly not all traits that psychologists consider relevant to describe human motivations. Teaching individuals to belief in their own abilities, to interpret the world around them optimistically and to understand the importance of taking self-responsibility could be one cost-effective way to counter-balance astronomically rising health care costs associated with an aging society (Bloom et al., 2011). It could even be one channel through which continuously increasing prevalence rates of avoidable illnesses such as obesity, diabetes and cardiovascular disease are curbed (Cobb-Clark et al., 2014). 
Many interventions that sought to change self-efficacy beliefs in adulthood as one method to improve life style choices tend to fail (See Ashford et al., 2010, for an overview), possibly due to their narrow focus on one single belief. Another reason is that noncognitive skills, including locus of control and the Big-Five personality traits, do not dramatically change in adulthood, even in the presence of severe life events (Cobb-Clark and Schurer, 2012, 2013). This does not say that the way how individuals perceive the world is hard-wired, ${ }^{24}$ but it is consistent with the suggestion that adulthood interventions would require more heavy artillery to tweak belief systems. Such heavy artillery was imposed on long-term recipients of income support from two regions in Canada (Self Sufficiency Project), by paying income subsidies that aimed at increasing labour supply (See Gottschalk, 2005). Although not aimed at improving self-efficacy per se, Gottschalk (2005) showed that internal control beliefs did change for individuals over the 36-month duration of the intervention.

It may however be more effective to target children or adolescents to improve perceptions of control (e.g. Almlund et al., 2011; Cunha and Heckman, 2009; Heckman and Masterov, 2007, for possible routes of intervention). Some promising initiatives are emerging world-wide that aim at strengthening resilience in school children. For instance, the Penn Resilience Program teaches elementary and middle school students to detect inaccurate thoughts, to evaluate the accuracy of their thoughts, and to challenge negative beliefs by considering alternative interpretations. The programme is not only conducted in the US, but was exported to Australia and the UK. ${ }^{25}$ Similar resilience programs are currently experimented with in Victoria, Australia, through public government funding and the Independent Schools Victoria association, ${ }^{26}$ and in the UK (UK Resilience Pro-

\footnotetext{
${ }^{24}$ For evidence against the hypothesis that character traits are hard-wired from young adulthood onwards, see Roberts et al. (2006).

${ }^{25}$ See Seligman et al. (2009) and www.ppc.sas.upenn.edu for a description of the program and its preliminary successes.

${ }^{26}$ For an overview of initiatives see www.is.vic.edu.au.
} 
gramme). Preliminary evidence from randomized controlled trials of these programmes suggest that at least in the short-run students depression scores, school attendance and performance improved (Challen et al., 2011). If these preliminary, positive returns to resilience interventions continue to show in the long-run, it may become standard in school curriculums to add a fourth $\mathrm{R}$ to education: Resilience.

\section{References}

Almlund, M., Lee Duckworth, A., Heckman, J.J., Kautz, T., 2011. Personality psychology and economics. In S.M. Eric A. Hanushek, L. Woessmann (Eds.), Handbook of the Economics of Education, vol. 4. North-Holland, pp. 1-181.

Ashford, S., Edmunds, J., French, D., 2010. What is the best way to change self-efficacy to promote lifestyle and recreational physical activity? a systematic review with meta analysis. British Journal of Health Psychology 15, 265-288.

Bandura, A., 1990. Reflections of non-ability determinants of competence. In R. Sternberg, John Kolligan Jr (Eds.), Competence Considered. Yale University Press, New Haven, Conn.

Bloom, D.E., Canning, D., Fink, G., 2011. Implications of population aging for economic growth. Program on the Global Demography of Aging Working Paper 64.

Blundell, R., MaCurdy, T., 1999. Labor supply: A review of alternative approaches. In O.C. Ashenfelter, D. Card (Eds.), Handbook of Labor Economics, vol. 3. Elsevier, pp. 1559-1695.

Bound, J., Schoenbaum, M., Stinebrickner, T., Waidman, T., 1999. The dynamic effects of health on the labor force transitions of older workers. Labour Economics 6, 179-202.

Bradley, C.J., Neumark, D., Luo, Z., Bednarek, H.L., 2007. Employment-contingent health insurance, illness, and labor supply of women: Evidence from married women with breast cancer. Health Economics 16, 719-737.

Bruin, J., 2011. newtest: command to compute new test @ONLINE. 
Caliendo, M., Cobb-Clark, D., Uhlendorff, A., 2014. Locus of control and job search strategies. Review of Economics and Statistics Forthcoming.

Cebi, M., 2007. Locus of control and human capital investment revisted. Journal of Human Resources 17, 919-932.

Challen, A., Noden, P., West, A., Machin, S., 2011. UK resilience programme: Evaluation: Final report. Tech. rep., Department of Education.

Chiteji, N., 2010. Time preference, noncognitive skills and well being across the life course: Do noncognitive skills encourage healthy behavior? American Economic Review: Papers \& Proceedings 100, 200-204.

Christensen, A.J., Johnson, J.A., 2002. Patient adherence with medical treatment regimens: An interactive approach. Current Directions in Psychological Science 11, pp. $94-97$.

Cobb-Clark, D., Kassenboehmer, S., Schurer, S., 2014. Healthy habits: What explains the connection between diet, exercise, and locus of control? Journal of Economic Behavior and Organization 98, 1-28.

Cobb-Clark, D., Schurer, S., 2012. The stability of the Big-Five personality traits. Economics Letter 115, 11-15.

Cobb-Clark, D., Schurer, S., 2013. Two economists' musings on the stability of locus of control. The Economic Journal 123, F358-F400.

Coleman, M., Deleire, T., 2003. An economic model of locus of control and the human capital investment decision. Journal of Human Resources 38, 701-721.

Cronbach, L.J., 1951. Coefficient alpha and the internal structure of tests. Psychometrika $16,297-334$.

Cunha, F., Heckman, J.J., 2008. Formulating, identifying and estimating the technology of cognitive and noncognitive skill formation. Journal of Human Resources 43, 738-782.

Cunha, F., Heckman, J.J., 2009. The economics and psychology of inequality and human development. Journal of the European Economics Association 7, 320-364. 
Cunha, F., Heckman, J.J., Schennach, S.M., 2010. Estimating the technology of cognitive and noncognitive skill formation. Econometrica 78.

Currie, J., Madrian, B., 1999. Health, health insurance and the labour market. In O. Ashenfelter, D. Card (Eds.), Handbook of Labor Economics. Elsevier, Amsterdam, pp. 3309-3416.

Dillon, A., Friedman, J., Serneels, P., 2014. Health information, treatment, and worker productivity: Experimental evidence from malaria testing and treatment among nigerian sugarcane cutters. Unpublished manuscript March.

Disney, R., Emmerson, C., Wakefield, M., 2006. Ill health and retirement in Britain: A panel data-based analysis. Journal of Health Economics 25, 621-649.

Duncan, G., Morgan, J., 1981. Sense of efficacy and changes in economic status - A comment on Andrisani. Journal of Human Resources 16, 649-657.

Fitzgerald, T.E., Tennen, H., Affleck, G., Pransky, G.S., 1993. The relative importance of dispositional appraisal in quality of life after coronary artery bypass surgery. Journal of Behavioral Medicine 16, 25-43.

Frijters, P., Haisken-DeNew, J., Shields, M., 2011. The increasingly mixed proportional hazard model: An application to socioeconomic status, health shocks and mortality $29,271-281$.

García-Gómez, P., 2011. Institutions, health shocks and labour market outcomes across europe. Journal of Health Economics 30, 200-213.

García-Gómez, P., van Kippersluis, H., O’Donnell, O., van Doorslaer, E., 2013. Longterm and spillover effects of health shocks on employment and income. Journal of Human Resources 48, 873-909.

García-Gómez, P., Jones, A., Rice, N., 2010. Health effects on labour market exits and entries. Labour Economics 17, 62-67.

García-Gómez, P., López-Nicolás, A., 2006. Health shocks, employment and income in the Spanish labour market. Health Economics 15, 997-1009. 
Goldsmith, A., Veum, J.R., Darity, W., 1996. The psychological impact of unemployment and joblessness. Journal of Socio-Economics 25, 333-358.

Gottschalk, P., 2005. Can work alter welfare recipients' beliefs? Journal of Policy Analysis and Management 24, 485-498.

Grossman, M., 1972. On the concept of health capital and the demand for health. Journal of Political Economy 80, 223-255.

Hadsell, L., 2010. Achievement goals, locus of control, and academic success in economics. American Economic Review Paper \& Proceedings 100, 272-276.

Heckman, J., Stixrud, J., Urzua, S., 2006. The effects of cognitive and noncognitive abilities on labor market outcomes and social behavior. Journal of Labour Economics $24,411-482$.

Heckman, J.J., Masterov, D.V., 2007. The productivity argument for investing in young children. Applied Economic Perspectives and Policy 29, 446-493.

Heineck, G., Anger, S., 2010. The returns to cognitive abilities and personality traits in Germany. Labour Economics 17, 535-546.

Heineck, G., Riphahn, R.T., 2009. Intergenerational transmission of educational attainment in germany - the last five decades. Journal of Economics and Statistics (Jahrbuecher fuer Nationaloekonomie und Statistik) 229, 36-60.

Johnson, J.A., Stoskopf, C.H., 2010. Comparative Health Systems. Global Perspectives. Jones and Bartlett Publishers, London.

Judge, T.A., Erez, A., Bono, J.E., Thoresen, C.J., 2002. Are measures of self-esteem, neuroticism, locus of control, and generalized self-efficacy indicators of a common core construct? Journal of Personality and Social Psychology 83, 693-710.

Karaca-Mandic, P., Norton, E.C., Dowd, B., 2012. Interaction terms in nonlinear models. Health Services Research 47, 255-274.

Klonowicz, T., 2001. Discontended people: Reactivity and locus of control as determinants of subjective well-being. European Journal of Psychology 15, 29-47. 
Mackenbach, J., Simon, J., Looman, C., Joung, I., 2002. Self-assessed health and mortality: Could psychological factors explain the association? International Journal of Epidemiology 31, 1162-1168.

Marshall, G., Wortman, C., Vickers, R., Kusulas, J., Hervig, L., 2014. The five-factor model of personality as a framework for personality - health research. Journal of Personality and Social Psychology 67, 278-286.

Piatek, R., Pinger, P., 2010. Maintaining (locus of) control? assessing the impact of locus of control on education decisions and wages. IZA Discussion Paper 5289.

Riphahn, R.T., 1999. Income and employment effects of health shocks. A test case for the German welfare state. Journal of Population Economics 12, 363-389.

Roberts, B.W., Walton, K.E., Viechtenbauer, W., 2006. Patterns of mean-level change in personality traits across the life course: A meta-analysis of longitudinal studies. Psychological Bulletin 126, 3-25.

Rotter, J., 1966. Generalized expectancies of internal versus external control of reinforcements. Psychological Monographs 80, 1-28.

Ryff, C.D., Friedman, E.M., Morozink, J.A., Tsenkova, V., 2012. Psychological resilience in adulthood and later life: Implications for health. Annual Review of Gerontology \& Geriatrics 32, 73-95.

Schurer, S., 2008. Discrete heterogeneity in the effects of health shocks on labour market outcomes. Melbourne Institute Working Paper 19/08.

Schwarzer, R., Warner, L.M., 2013. Perceived self-efficacy and its relationship to resilience. In S. Prince-Embury, D.H. Saklofske (Eds.), Resilience in Children, Adolescents, and Adults. Springer, New York.

Seligman, M., 2011. Building resilience. Harvard Business Review April.

Seligman, M.E.P., Ernst, R.M., annd Karen Reivich, J.G., Linkins, M., 2009. Positive education: positive psychology and classroom interventions. Oxford Review of Education $35,293-311$. 
Smith, J.P., 1999. Healthy bodies and thick wallets. Journal of Economic Perspectives $13,145-166$.

Smith, J.P., 2005. Consequences and predictors of new health events. In D. Wise (Ed.), Analyses in the Economics of Aging. NBER, pp. 213-240.

Strudler Wallston, B., Wallston, K.A., 1978. Locus of control and health: A review of the literature. Health Education Monographs 6, 107-117.

Thompson, S., 1981. Will it hurt less if I can control it? A complex answer to a simple question. Psychological Bulletin 90, 89-101.

Tough, P., 2012. How children succeed: Grit, curiosity, and the hidden power of character. Houghton Mifflin Harcourt, Boston, MA.

Van Doorslaer, E., Masseria, C., 2004. Income-related inequality in the use of medical care in 21 OECD countries. Working Paper 14, OECD.

Wagner, G., Frick, J., Schupp, J., 2006. The German Socio-Economic Panel Study (SOEP) - scope, evolution and enhancements. Schmollers Jahrbuch 127, 139-169.

Watson, D., Hubbard, B., 1996. Adaptational style and dispositional structure: Coping in the context of the five-factor model. Journal of Personality 64, 737-774.

Weisz, J., Stipek, D., 1982. Competence contingency, and the development of perceived control. Human Development 25, 250-281.

Wing Han Au, D., Crossley, T.F., Schellhorn, M., 2005. The effect of health changes and long-term health on the work activity of older Canadians. Health Economics 14, 999-1018. 
Table 1: Components of locus of control recorded in 1994-1996

\begin{tabular}{lcccccc}
\hline Variable & Mean & Std. Dev. & Min. & Max. & N & $\begin{array}{c}\text { Cronbach's } \alpha \\
\text { if item omitted }\end{array}$ \\
\hline Scale: 1 Fully applies - 4 Does not apply & & & & & & \\
\hline Q. 1 Have Control Over Own Life & 1.886 & 0.683 & 1 & 4 & 4623 & 0.7328 \\
Q. 2 Plans Are Unsuccessful & 2.069 & 0.789 & 1 & 4 & 4613 & 0.6906 \\
Q. 3 Behavior Determines Life & 1.858 & 0.655 & 1 & 4 & 4619 & 0.7454 \\
Q. 4 No One Can Escape Their Destiny & 2.477 & 0.924 & 1 & 4 & 4616 & 0.7244 \\
Q. 5 I Get Something Because Of Luck & 1.942 & 0.735 & 1 & 4 & 4619 & 0.7127 \\
Q. 6 Plans Turn To Reality & 2.205 & 0.660 & 1 & 4 & 4619 & 0.728 \\
Q. 7 Something Unforseen Happens & 2.183 & 0.796 & 1 & 4 & 4610 & 0.6721 \\
Q. 8 The Outcome Is Always Different & 2.152 & 0.835 & 1 & 4 & 4613 & 0.6773 \\
\hline Cronbach's $\alpha$ with eight items & & & & & & 0.7388 \\
\hline
\end{tabular}

$\mathrm{b}$ : Takes the value 1 if the predicted first factor value is greater than the value of the $75^{\text {th }}$ percentile $\left(0\right.$ if $\leq 75^{t h}$ percentile). 


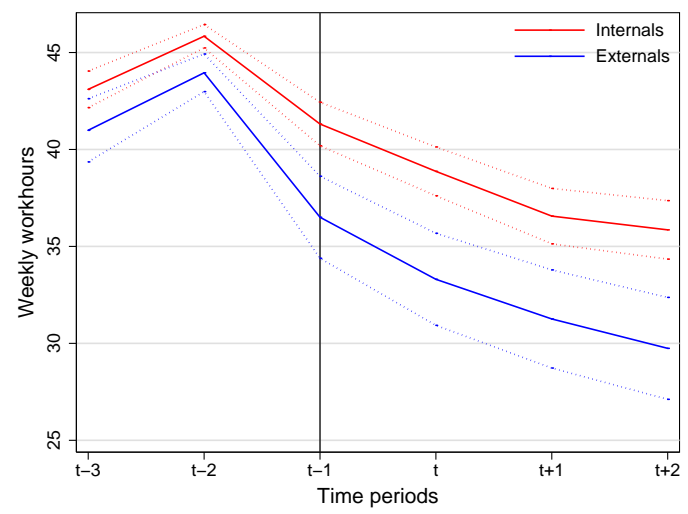

(a) Working-hours

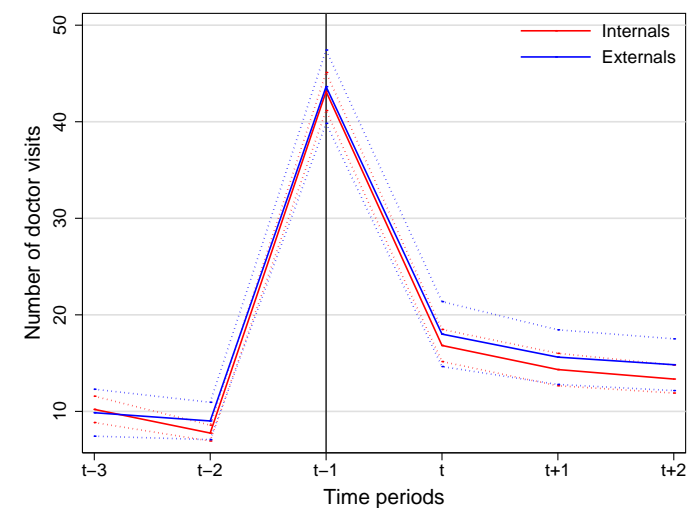

(b) Doctor visits

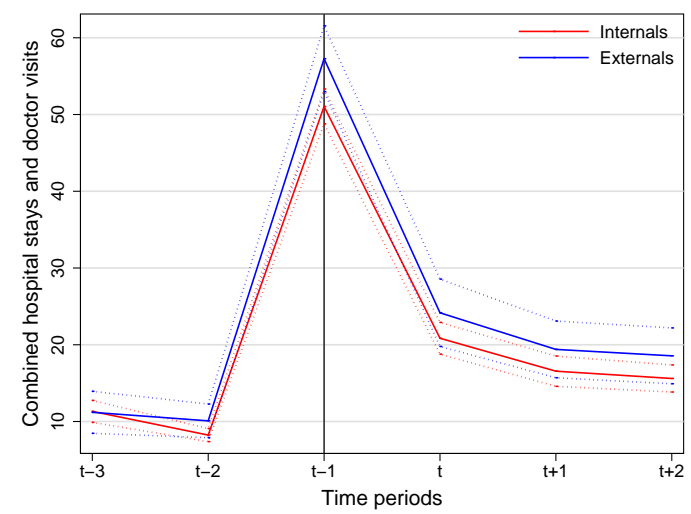

(d) Combined doctor and hospital visits

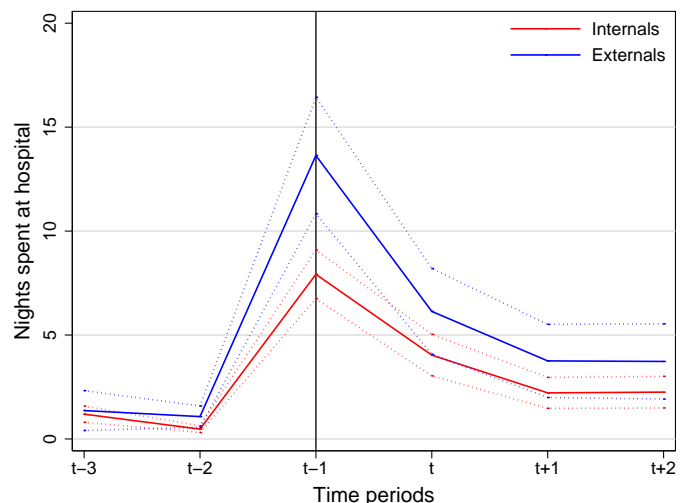

(c) Nights at hospital

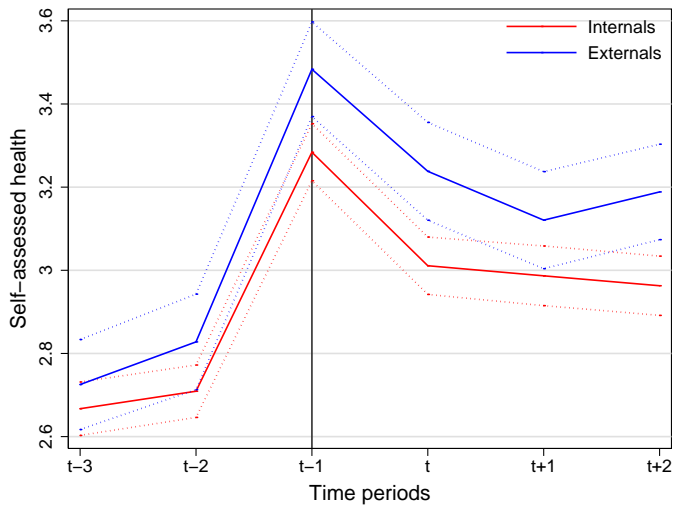

(e) Self-assessed health

Figure 1: Evolution of working-hours, health, and health care utilisation before, during, and after experiencing a health shock ( $\mathrm{t}-1)$, by locus of control) 
Table 2: Selected estimation results: Marginal probability effects

\begin{tabular}{|c|c|c|c|c|c|c|}
\hline & \multicolumn{2}{|c|}{$\begin{array}{l}\text { Part-time work } \\
\text { ( }<20 \text { hours) }\end{array}$} & \multicolumn{2}{|c|}{$\begin{array}{l}\text { Dropping out of } \\
\text { labour force }\end{array}$} & \multicolumn{2}{|c|}{$\begin{array}{c}\text { Registered } \\
\text { unemployment }\end{array}$} \\
\hline & ME & SE & $\mathrm{ME}$ & SE & ME & SE \\
\hline Difference in effect of health shock & $0.067^{* *}$ & 0.026 & $0.049 * * *$ & 0.013 & -0.011 & 0.018 \\
\hline \multicolumn{7}{|l|}{ between 10th-90th pctl of locus of control } \\
\hline Effect of external control (Std, for shock $=0$ ) & 0.002 & 0.002 & $0.002 * * *$ & 0.001 & 0.001 & 0.001 \\
\hline Average health in 1994-1996 (Std) & $0.008 * * *$ & 0.003 & $0.004 * * *$ & 0.001 & 0.003 & 0.002 \\
\hline Age $55-60$ years (Base: 25 to 29 years) & $0.088 * * *$ & 0.014 & $0.026 * * *$ & 0.007 & $0.042 * * *$ & 0.009 \\
\hline Years of education (Std) & $-0.011 * * *$ & 0.003 & $-0.002 * *$ & 0.001 & $-0.014 * * *$ & 0.002 \\
\hline Willingness to take risk (Std) & $-0.006 * *$ & 0.003 & $-0.004 * * *$ & 0.001 & -0.001 & 0.002 \\
\hline Being pessimistic (Std) & $0.010 * * *$ & 0.003 & 0.000 & 0.001 & $0.011 * * *$ & 0.002 \\
\hline Being conscientious (Std) & $-0.011 * * *$ & 0.003 & $-0.005^{* * *}$ & 0.001 & $-0.003^{*}$ & 0.002 \\
\hline Being extraverted (Std) & 0.003 & 0.003 & $0.002 * *$ & 0.001 & 0.000 & 0.002 \\
\hline Being agreeable (Std) & 0.002 & 0.002 & 0.001 & 0.001 & 0.003 & 0.002 \\
\hline Being open to experience (Std) & 0.003 & 0.003 & $0.003 * * *$ & 0.001 & -0.002 & 0.002 \\
\hline Being neurotic (Std) & $0.009 * * *$ & 0.002 & $0.004 * * *$ & 0.001 & 0.003 & 0.002 \\
\hline Cognitive ability (Std) & -0.002 & 0.003 & $-0.002 * *$ & 0.001 & 0.003 & 0.002 \\
\hline Hourly wage in $\mathrm{t}-2$ (Ln) & $-0.044 * * *$ & 0.005 & -0.002 & 0.002 & -0.015 & 0.003 \\
\hline Regional unemployment rate (Std) & $0.012 *$ & 0.008 & -0.002 & 0.004 & $0.015^{* *}$ & 0.006 \\
\hline Difference in tenure at firm (10th-90th pctl) & $-0.012 * * *$ & 0.001 & $-0.003^{* * *}$ & 0.001 & $-0.007 * * *$ & 0.001 \\
\hline AIC & \multicolumn{2}{|c|}{11101.6} & \multicolumn{2}{|c|}{3609.4} & \multicolumn{2}{|c|}{6199.9} \\
\hline AIC in model without interaction term & \multicolumn{2}{|c|}{11103.3} & \multicolumn{2}{|c|}{3614.3} & \multicolumn{2}{|c|}{6196.6} \\
\hline McFadden R-squared & \multicolumn{2}{|c|}{0.1221} & \multicolumn{2}{|c|}{0.1061} & \multicolumn{2}{|c|}{0.1783} \\
\hline McFadden R-squared in model without interaction term & \multicolumn{2}{|c|}{0.1220} & \multicolumn{2}{|c|}{0.1049} & \multicolumn{2}{|c|}{0.1788} \\
\hline Hosmer-Lemeshow goodness of fit test & \multicolumn{2}{|c|}{$\operatorname{Pass}^{a}$} & \multicolumn{2}{|c|}{ Pass } & \multicolumn{2}{|c|}{ Pass } \\
\hline Pregibon's functional form test & \multicolumn{2}{|c|}{ Pass } & \multicolumn{2}{|c|}{ Pass } & \multicolumn{2}{|c|}{ Pass } \\
\hline NT & \multicolumn{2}{|c|}{22,876} & \multicolumn{2}{|c|}{23,102} & \multicolumn{2}{|c|}{23,234} \\
\hline Number of individuals & \multicolumn{2}{|c|}{2,505} & \multicolumn{2}{|c|}{2,506} & \multicolumn{2}{|c|}{2,516} \\
\hline Number of time periods & \multicolumn{2}{|l|}{14} & \multicolumn{2}{|l|}{14} & \multicolumn{2}{|l|}{14} \\
\hline Number of individuals for shock $=1$ and outcome $=1$ & 188 & & 63 & & 96 & \\
\hline
\end{tabular}

Interaction effects are calculated according to Karaca-Mandic et al. (2012) in STATA. Standard errors are calculated with the Delta method. Full estimation results are presented in Table A.4 in the Online Appendix. a: Pass indicates fail to reject the $H_{0}$ hypothesis at $10 \%$ and higher. 


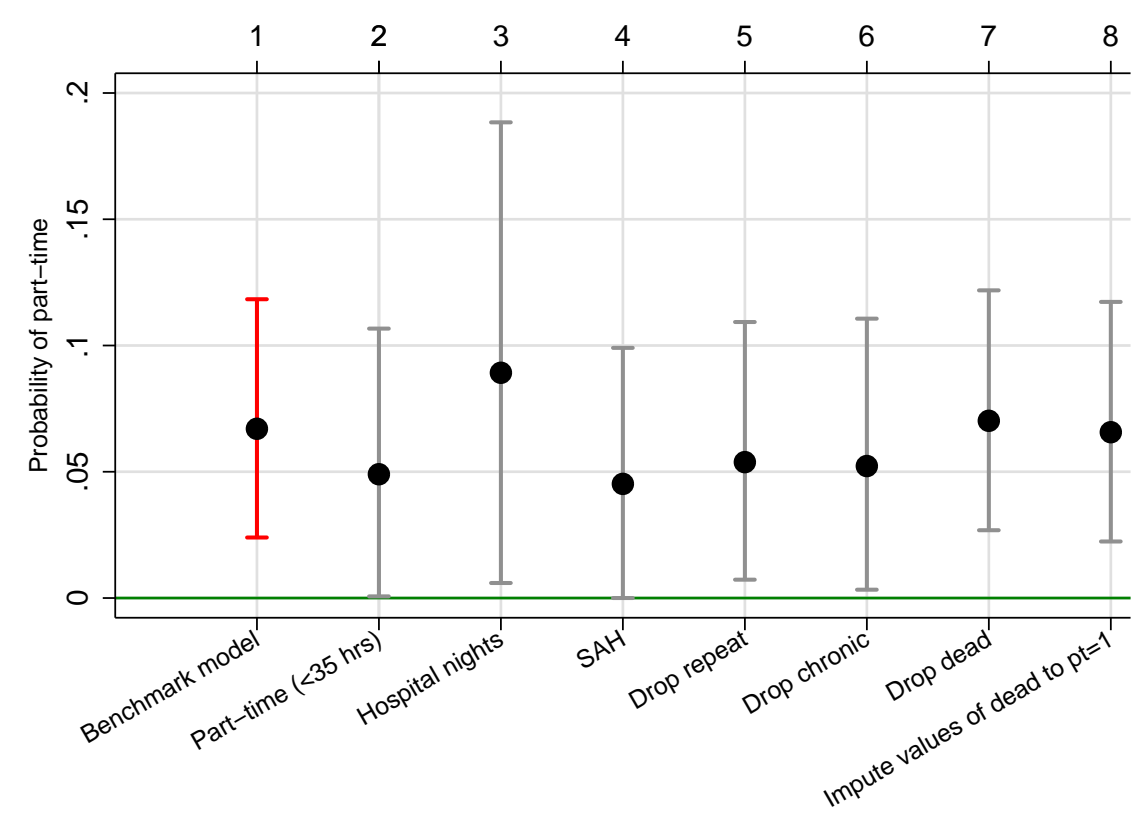

Figure 2: Robustness of interaction effect with respect to definition of part-time, definition of health shock, and sample definitions

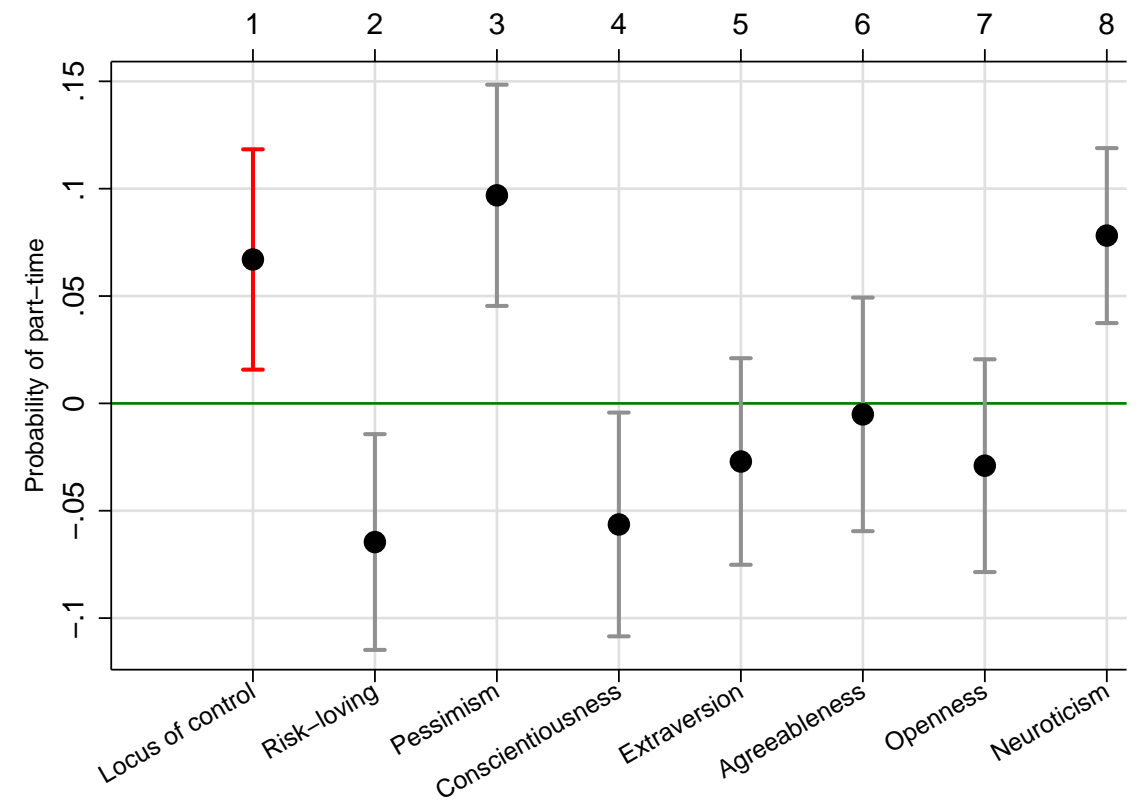

Figure 3: Interaction effects between health shock and other non-cognitive skills 


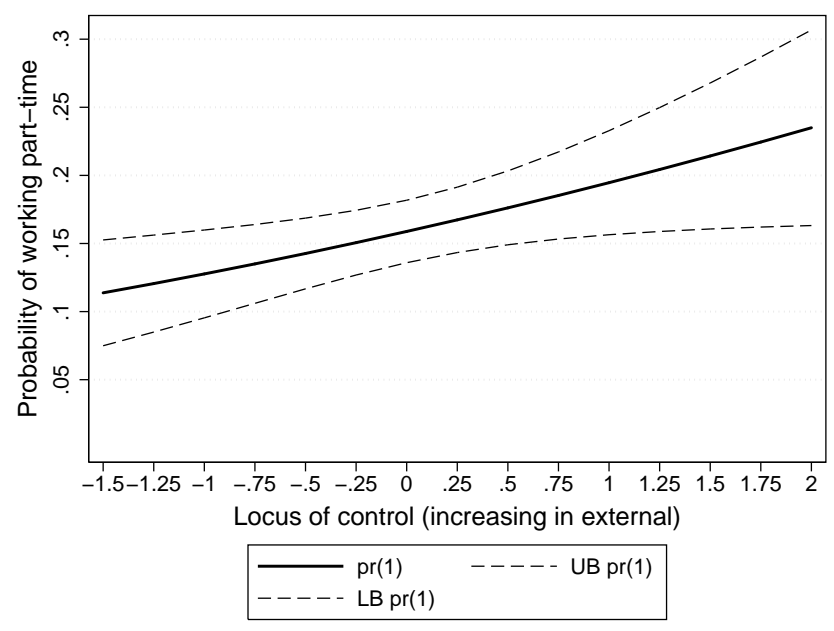

(a) Locus of control

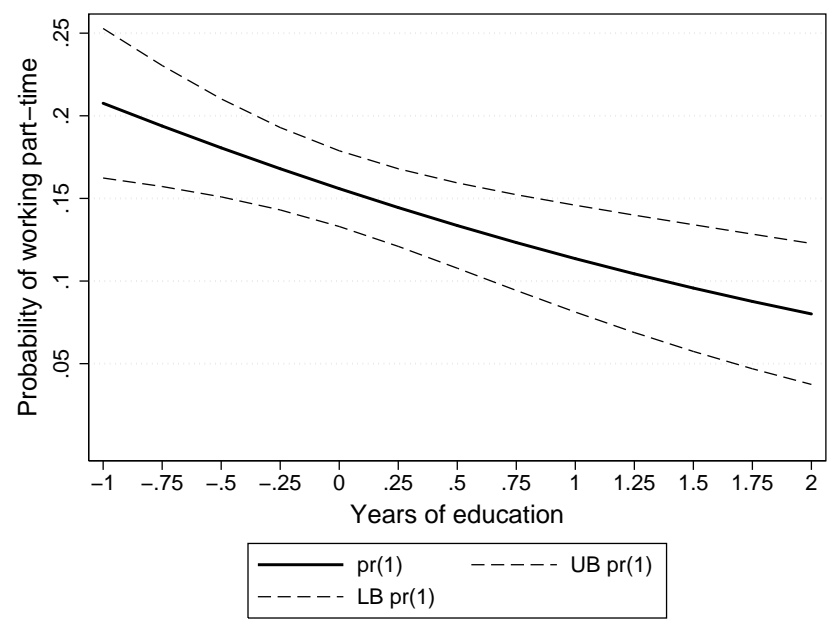

(b) Education

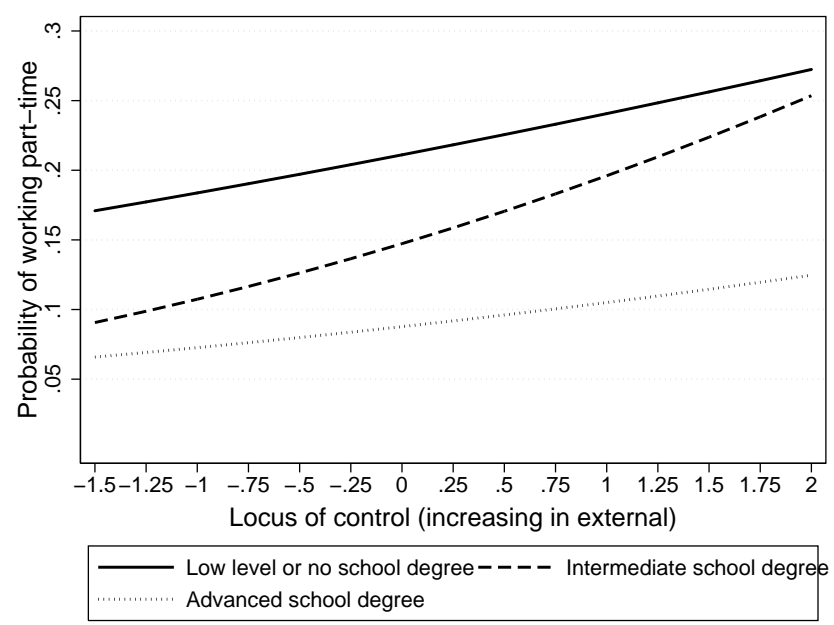

(c) By education groups

Figure 4: Simulation of interaction effect of locus of control on probability of becoming part-time after having experienced a health shock, by education 


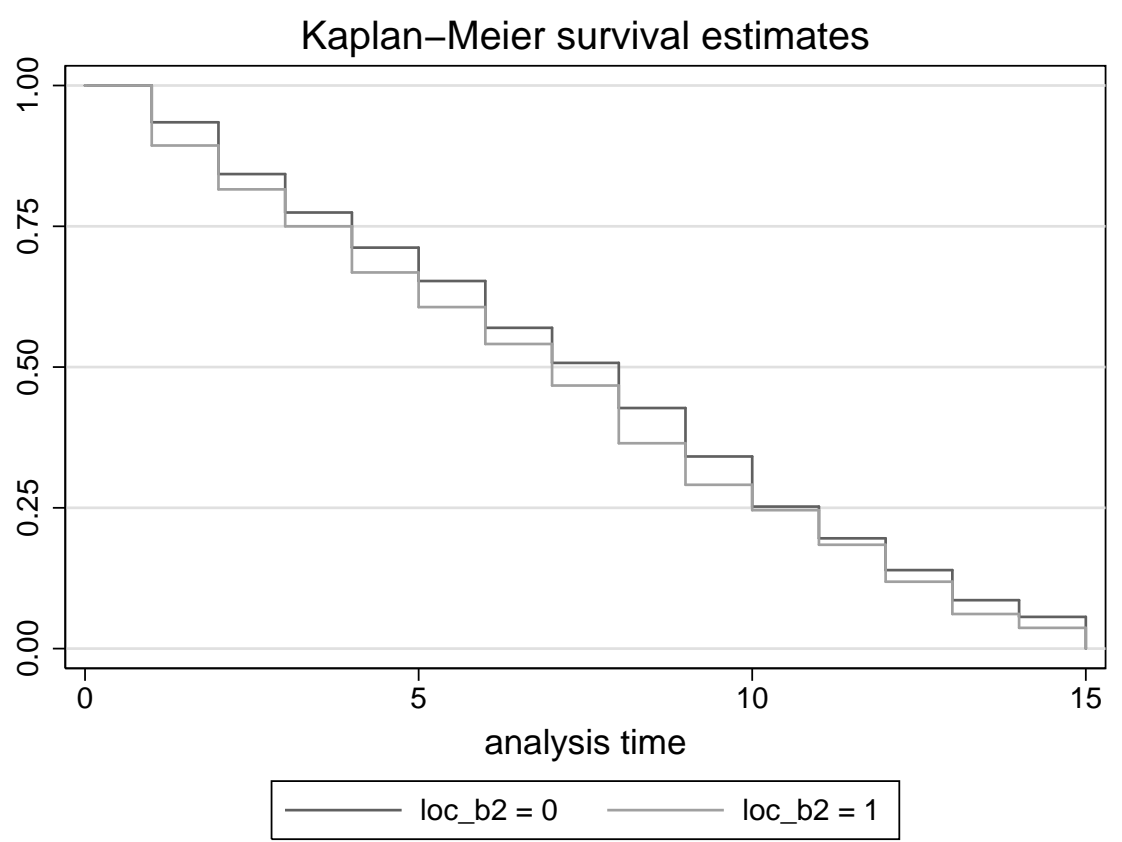

Figure 5: Kaplan-Meier survival function: Probability of death between externally and internally controlled individuals

Table 3: Hazard of dying by age, initial health, education, shocks, and locus of control

\begin{tabular}{llllll}
\hline & Full sample & $<50$ years & $50-59$ years & $60-69$ years & 70 years \\
\hline Age & $1.097^{* * *}$ & $1.056^{* * *}$ & $1.101^{* *}$ & $1.104^{* * *}$ & $1.135^{* * *}$ \\
Health (Std) & $1.490^{* * *}$ & $1.422^{* * *}$ & $1.428^{* * *}$ & $1.452^{* * *}$ & $1.778^{* * *}$ \\
Health shock & $2.427^{* * *}$ & $3.574^{* * *}$ & $3.632^{* * *}$ & $2.701^{* * *}$ & 1.184 \\
External locus of control (0,1) & 1.095 & 1.211 & 1.141 & 1.189 & 0.865 \\
Health shock $\times$ External LOC & 1.352 & 0.488 & 1.264 & 1.247 & $2.732^{* *}$ \\
Years of education & $0.957^{* *}$ & 0.976 & $0.852^{* * *}$ & 0.983 & 1.022 \\
Married (0,1) & $0.700^{* * *}$ & $0.281^{* * *}$ & 0.846 & 0.959 & 1.055 \\
NT & 53159 & 35143 & 10021 & 5784 & 2211 \\
Number of deaths & 479 & 73 & 100 & 157 & 149 \\
Number of deaths among externals & 53 & 2 & 13 & 18 & 20 \\
\hline
\end{tabular}

Reported are hazard ratios obtained from a Cox proportional hazard regression. All predictors pass a test of proportionality $* p<0.10, * * p<0.05, * * * p<0.01$

\section{ONLINE APPENDIX}




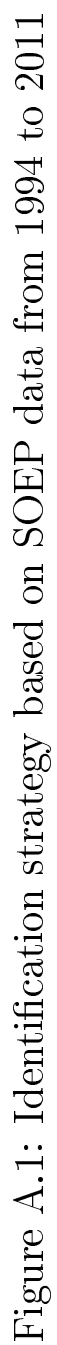

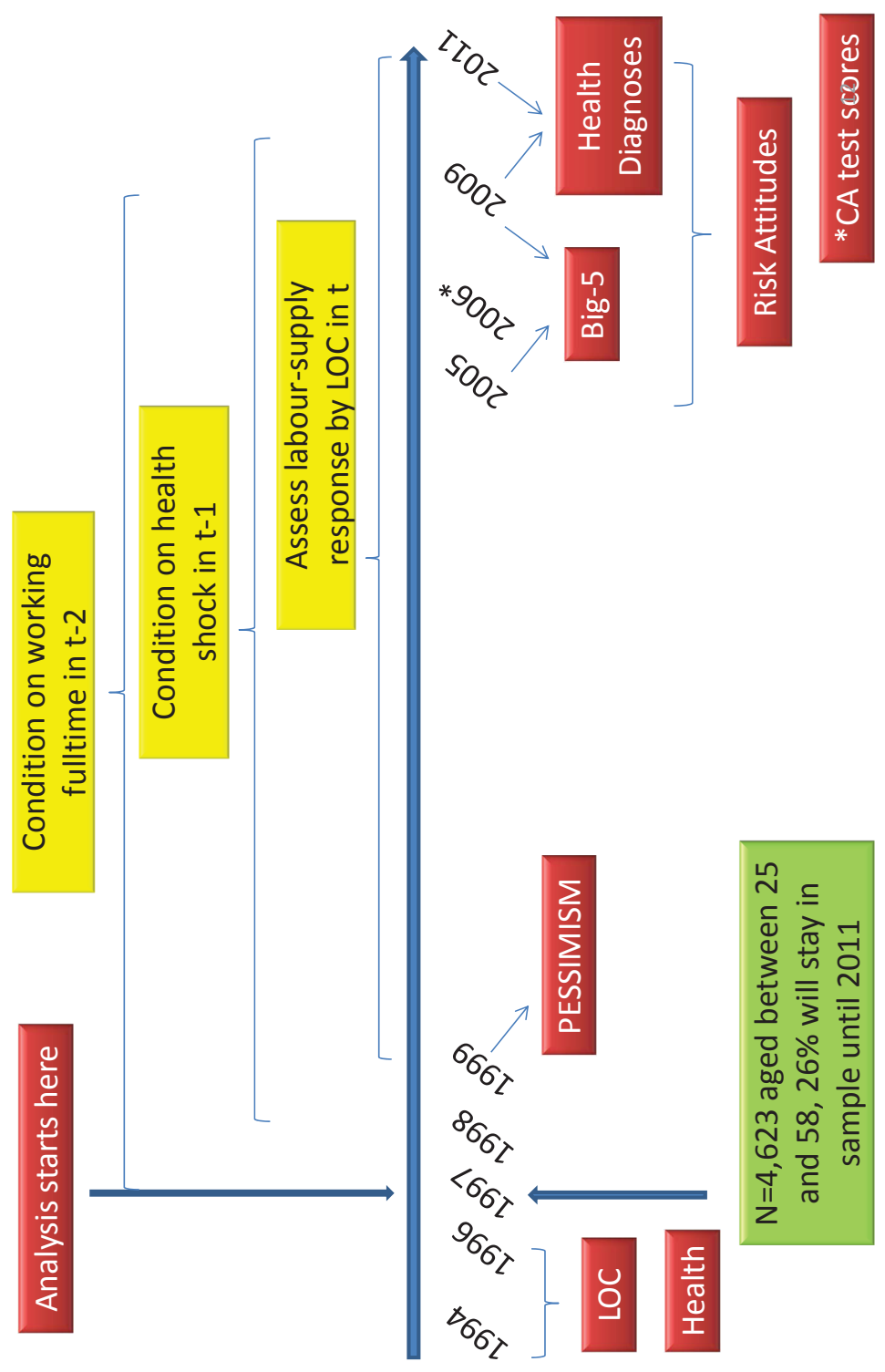


Table A.1: Illustration of three-year interval generation for analysis

\begin{tabular}{|c|c|c|c|c|c|c|c|c|}
\hline & $t-2$ & $t-1$ & $\mathrm{t}$ & & & & & \\
\hline & & $\mathrm{t}-2$ & $t-1$ & $t$ & & & & \\
\hline 1 & 1997 & 1998 & 1999 & & & & & \\
\hline 2 & & 1998 & 1999 & 2000 & & & & \\
\hline 3 & & & & $\ldots$ & $\ldots \ldots$ & & & \\
\hline$\vdots$ & & & & & $\vdots$ & $\vdots$ & & \\
\hline 12 & & & & & 2008 & 2009 & 2010 & \\
\hline 13 & & & & & & 2009 & 2010 & 2011 \\
\hline
\end{tabular}

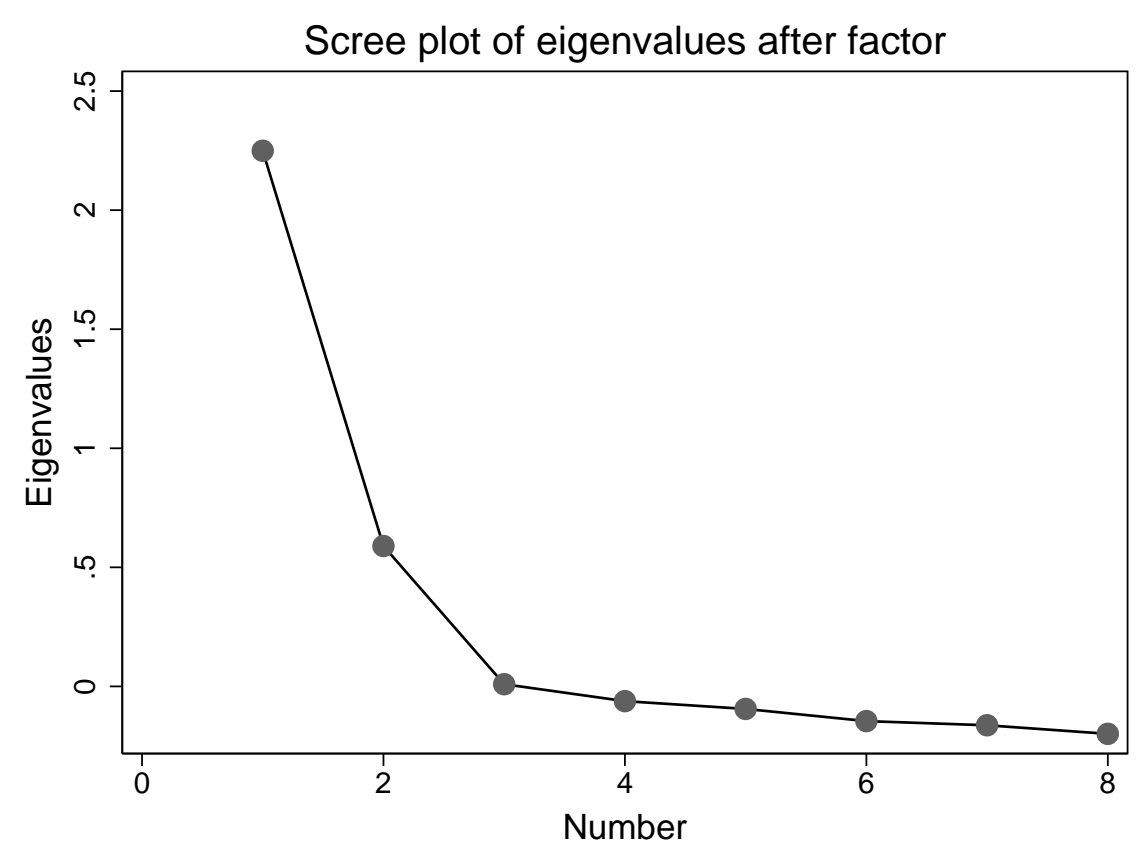

Figure A.2: Scree plot of factor loadings 


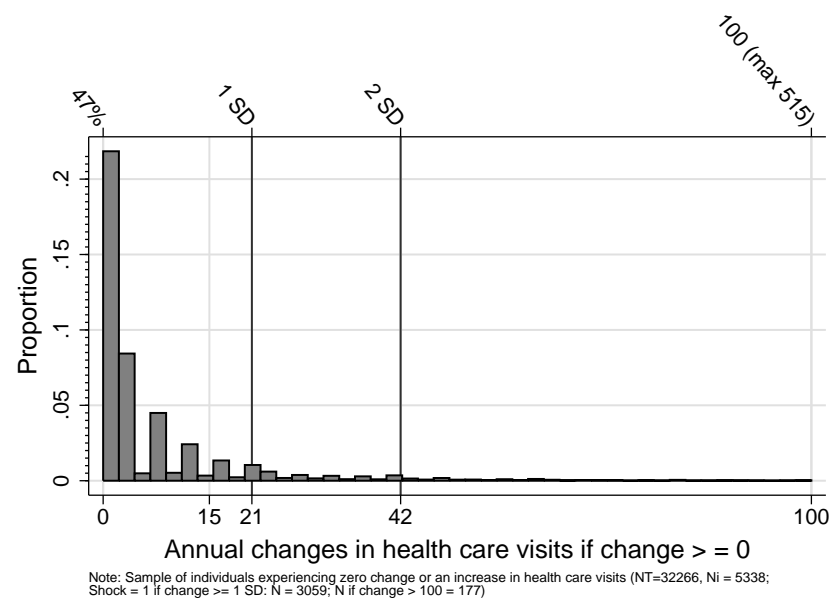

(a) Changes in health care visits

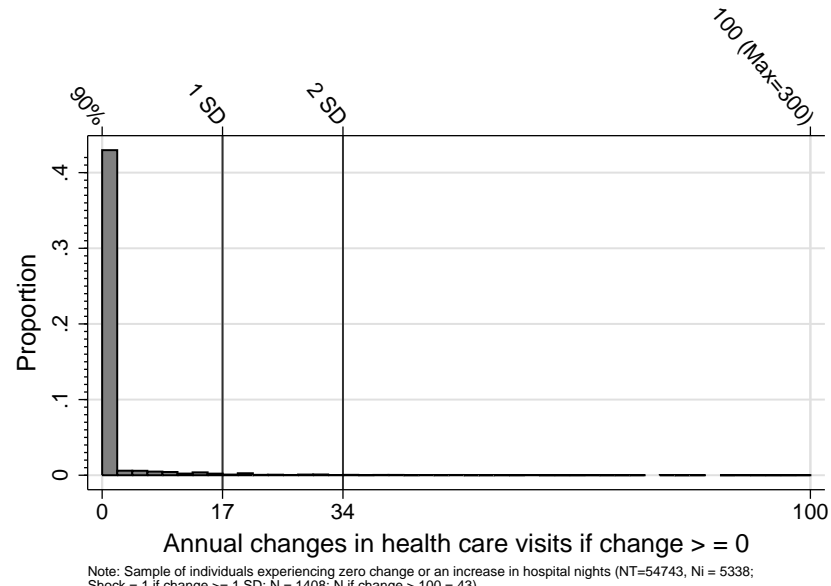

(b) Nights spent at hospital

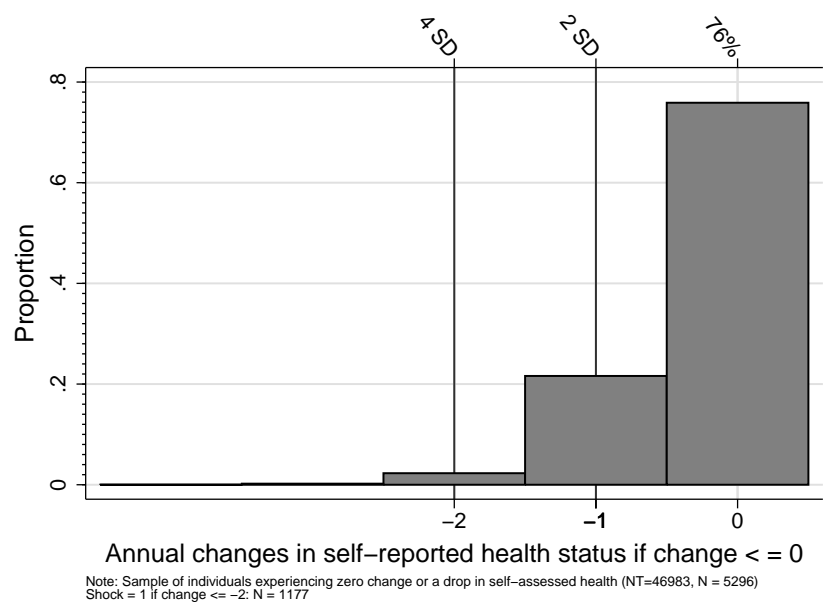

(c) Self-assessed health

Figure A.3: Changes in health care visits, hospital nights and self-assessed health which are used to construct a health shock indicator 
Table A.2: Determinants of a health shock: Marginal probability effects

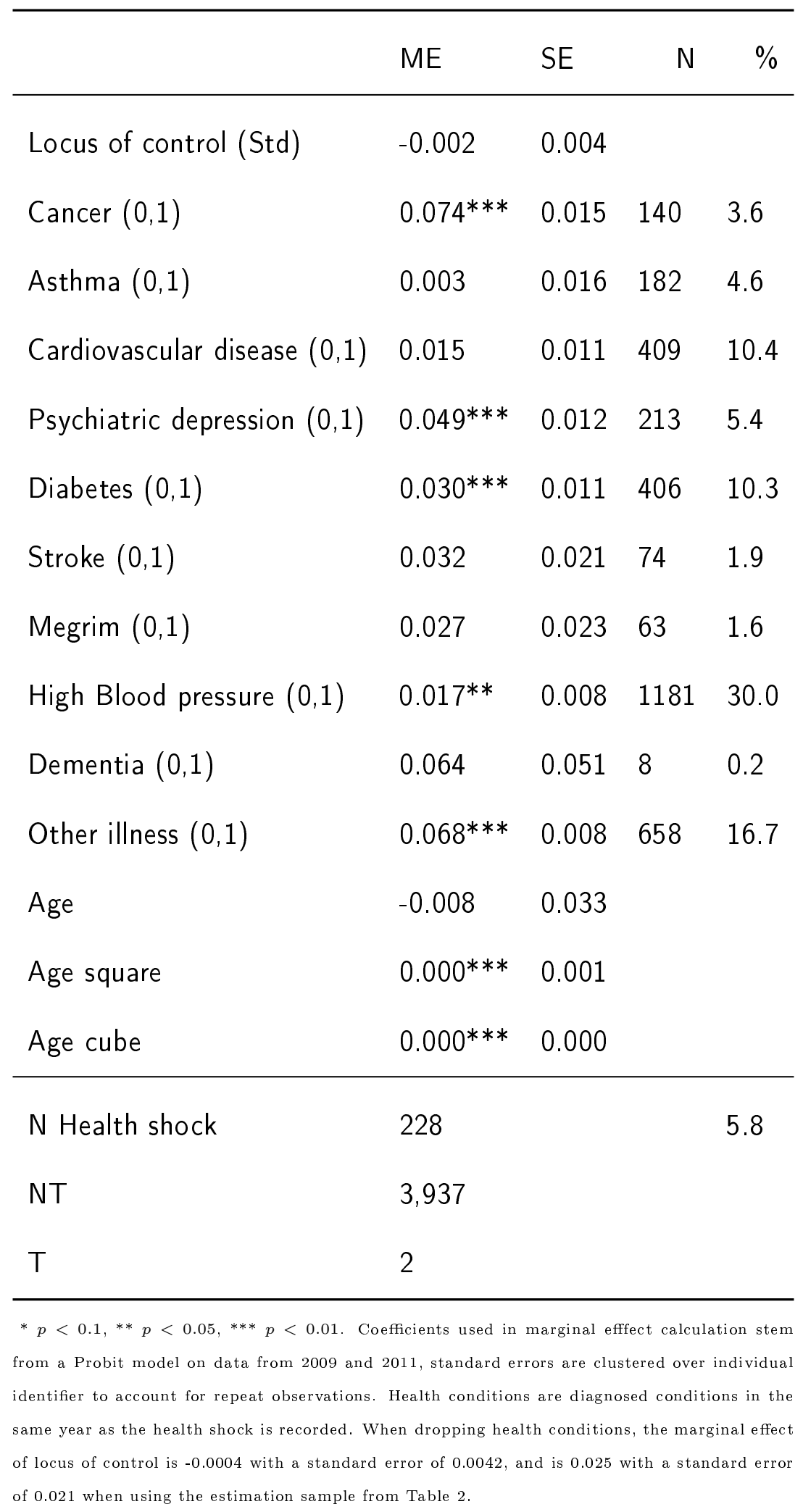


Local polynomial smooth

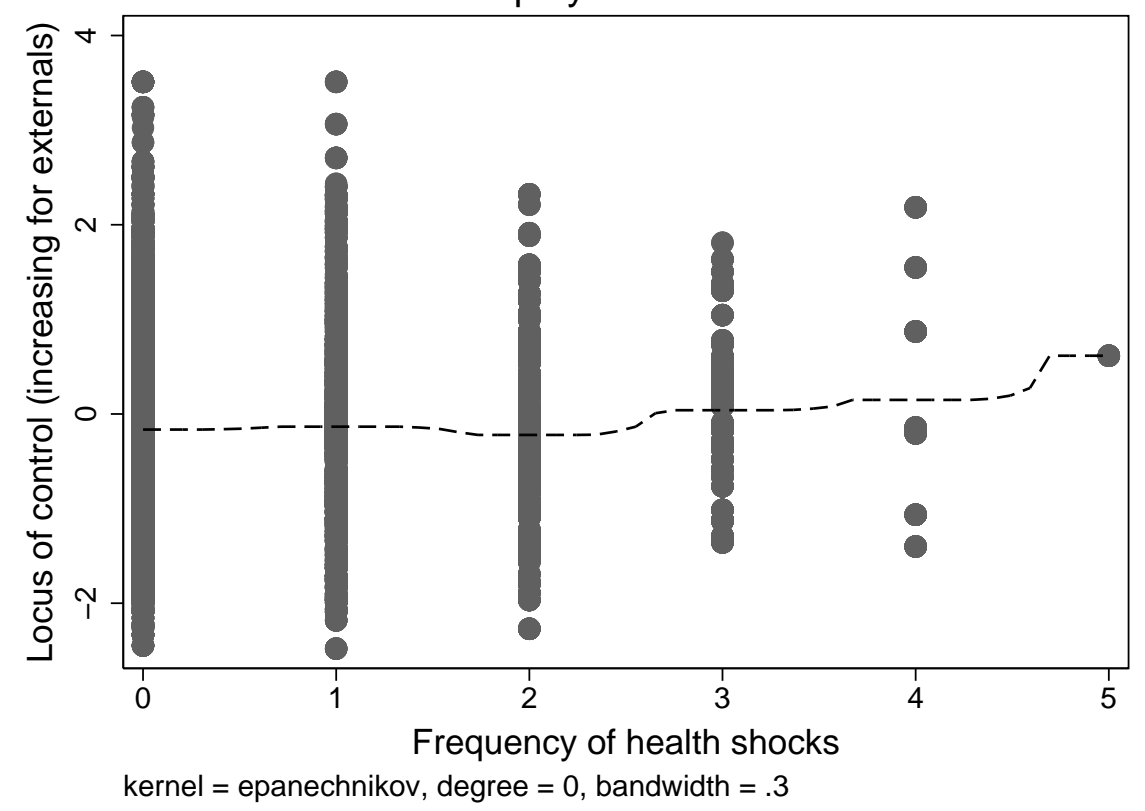

Figure A.4: Relationship between frequency of shock and locus of control 


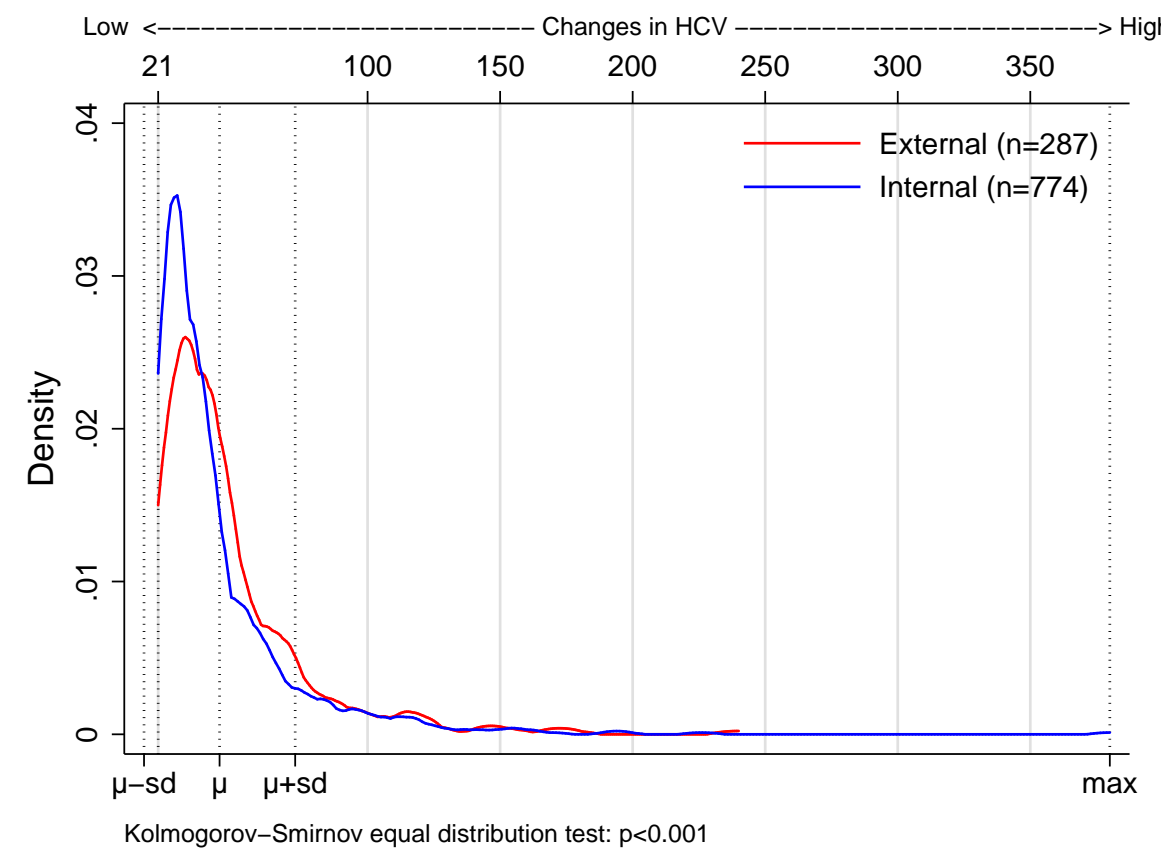

Figure A.5: Relationship between intensity of health shock and locus of control 
Table A.3: Differences in distribution of key variables between internals and externals

\begin{tabular}{|c|c|c|c|}
\hline & External $^{a}$ & Internal $^{b}$ & $\mathrm{p}$-value \\
\hline \multicolumn{4}{|l|}{ Measures of labor supply } \\
\hline Part-time $(<20$ hours per week $)(0,1)$ & 0.102 & 0.071 & 0.000 \\
\hline Part-time ( $<35$ houra per week) $(0,1)$ & 0.153 & 0.111 & 0.000 \\
\hline Drop-out from labour force $(0,1)$ & 0.025 & 0.013 & 0.000 \\
\hline Registered unemployed $(0,1)$ & 0.053 & 0.033 & 0.000 \\
\hline Work-hours per week in $t$ & 39.134 & 41.975 & 0.000 \\
\hline \multicolumn{4}{|l|}{ Health care visits and health } \\
\hline Number of health care visits & 8.148 & 7.885 & 0.241 \\
\hline Nights spent at hospital & 1.173 & 0.732 & 0.000 \\
\hline Number of doctor visits & 6.975 & 7.153 & 0.357 \\
\hline Self-assessed health (1:Excellent - 5: Poor) & 2.514 & 2.477 & 0.002 \\
\hline Changes in health care visits & 0.463 & 0.265 & 0.452 \\
\hline Changes in nights spent at hospitals & 0.118 & 0.090 & 0.781 \\
\hline Changes in doctor visits & 0.344 & 0.186 & 0.487 \\
\hline Change in self-assessed health & 0.040 & 0.031 & 0.432 \\
\hline \multicolumn{4}{|l|}{ Definition of health shock } \\
\hline Health care visits $(0,1)$ [Changes greater than 21$]$ & 0.050 & 0.045 & 0.107 \\
\hline Hospital nights $(0,1)[$ Changes greater than 17$]$ & 0.015 & 0.010 & 0.000 \\
\hline $\begin{array}{l}\text { Self-assessed health }(0,1) \text { [Drop in SAH }>2 \text { ] } \\
\text { Control variables }\end{array}$ & & 0.003 \\
\hline Age & 43.668 & 44.602 & 0.000 \\
\hline Years of education (7.5-18) & 11.062 & 12.829 & 0.000 \\
\hline Willingness to takes risks ( 0 : low - 10: high) (Std) & -0.028 & 0.179 & 0.000 \\
\hline Pessimistic (Std) & 2.245 & 2.174 & 0.000 \\
\hline Conscientiousness (Std) & 0.153 & 0.079 & 0.000 \\
\hline Extraversion (Std) & 0.023 & 0.034 & 0.396 \\
\hline Agreeableness (Std) & 0.002 & -0.029 & 0.020 \\
\hline Openness to Experience (Std) & -0.024 & 0.080 & 0.000 \\
\hline Neuroticism (Std) & 0.036 & -0.122 & 0.000 \\
\hline Test score on symbol digit modalities test (1-60) & 3.632 & 3.554 & 0.605 \\
\hline Proportion test scores is missing & 0.829 & 0.850 & 0.000 \\
\hline Accumulated part-time experience until t-2 & 0.383 & 0.429 & 0.031 \\
\hline Working hours in $\mathrm{t}-2$ (conditioned on $>37$ hours) & 43.629 & 45.153 & 0.000 \\
\hline Proportion unemployed in state and time $\mathrm{t}$ & 0.096 & 0.104 & 0.000 \\
\hline Average hourly wage in $t-2$ when full-time employed & 13.980 & 16.847 & 0.000 \\
\hline Average years spent at firm in $\mathrm{t}-2$ & 11.550 & 11.765 & 0.145 \\
\hline Firm size: $21-200$ employees in $t-2(0,1)$ & 0.286 & 0.273 & 0.064 \\
\hline Firm size: 20 or less employees in t-2 $(0,1)$ & 0.236 & 0.212 & 0.000 \\
\hline Firm size: $201-2000$ employees in $t-2(0,1)$ & 0.255 & 0.219 & 0.000 \\
\hline Firm size: $2001-20000$ employees in $\mathrm{t}-2(0,1)$ & 0.205 & 0.265 & 0.000 \\
\hline Self-employed in $\mathrm{t}-2(0,1)$ & 0.019 & 0.032 & 0.000 \\
\hline Married $(0,1)$ & 0.743 & 0.764 & 0.002 \\
\hline Foreigner $(0,1)$ & 0.158 & 0.066 & 0.000 \\
\hline Schleswig-Holstein $(0,1)$ & 0.018 & 0.026 & 0.002 \\
\hline Hamburg $(0,1)$ & 0.004 & 0.011 & 0.000 \\
\hline Lower Saxony $(0,1)$ & 0.076 & 0.083 & 0.109 \\
\hline Bremen $(0,1)$ & 0.006 & 0.006 & 0.752 \\
\hline Northrhine-Westphalia $(0,1)$ & 0.201 & 0.205 & 0.551 \\
\hline Hessia $(0,1)$ & 0.079 & 0.051 & 0.000 \\
\hline Rhineland-Palatinate $(0,1)$ & 0.058 & 0.054 & 0.245 \\
\hline Baden-Wurttemberg $(0,1)$ & 0.177 & 0.111 & 0.000 \\
\hline Bavaria $(0,1)$ & 0.145 & 0.148 & 0.658 \\
\hline Saarland $(0,1)$ & 0.008 & 0.006 & 0.083 \\
\hline Berlin $(0,1)$ & 0.020 & 0.035 & 0.000 \\
\hline Brandenburg $(0,1)$ & 0.043 & 0.044 & 0.678 \\
\hline Mecklenburg-Vorpommern $(0,1)$ & 0.011 & 0.034 & 0.000 \\
\hline Saxony $(0,1)$ & 0.059 & 0.093 & 0.000 \\
\hline Saxen-Anhalt $(0,1)$ & 0.047 & 0.046 & 0.973 \\
\hline Thuringia $(0,1)$ & 0.047 & 0.048 & 0.733 \\
\hline
\end{tabular}

a: External: locus of control $>75^{t h}$ percentile. b: Internal: locus of control $\leq 75^{t h}$ percentile. Estimation sample is $\mathrm{NT}=22,876$, and $\mathrm{N}=2,505$. Omitted are year-, industry-, and occupation-dummy 
Table A.4: Full estimation results: Coefficients from Probit models

\begin{tabular}{|c|c|c|c|c|}
\hline & \multicolumn{4}{|c|}{ Dependent variable: Probability of } \\
\hline & $\begin{array}{l}\text { Part-time } \\
(<20 \mathrm{hrs})\end{array}$ & $\begin{array}{l}\text { Dropout from } \\
\text { labour force }\end{array}$ & $\begin{array}{l}\text { Registered } \\
\text { unemployed }\end{array}$ & $\begin{array}{l}\text { Part-time } \\
\text { ( }<35 \text { hours })\end{array}$ \\
\hline Self-assessed health (Std) (Avg. from 94-96) & $\begin{array}{l}0.0607 * * * \\
(0.0204)\end{array}$ & $\begin{array}{l}0.0987 * * * \\
(0.0305)\end{array}$ & $\begin{array}{l}0.0400^{*} \\
(0.0236)\end{array}$ & $\begin{array}{l}0.0619 * * * \\
(0.0204)\end{array}$ \\
\hline Locus of control (Std) (Avg. from 94-96) & $\begin{array}{l}0.0282 \\
(0.0201)\end{array}$ & $\begin{array}{l}0.0834 * * * \\
(0.0306)\end{array}$ & $\begin{array}{l}0.0269 \\
(0.0255)\end{array}$ & $\begin{array}{l}0.0308 \\
(0.0191)\end{array}$ \\
\hline Health shock in $t-1$ & $0.423^{* * *}$ & $0.437 * * *$ & $\begin{array}{l}0.404^{* * *} \\
(0.0638)\end{array}$ & $0.371^{* * *}$ \\
\hline Health shock $\times$ locus of control & $\begin{array}{l}0.127 * * \\
(0.0558)\end{array}$ & $\begin{array}{l}0.221^{* * *} \\
(0.0750)\end{array}$ & $\begin{array}{l}-0.0517 \\
(0.0653)\end{array}$ & $\begin{array}{l}0.0773 \\
(0.0537)\end{array}$ \\
\hline Age-group 30-34 (Base: 25-29) & $\begin{array}{l}-0.112 \\
(0.0879)\end{array}$ & $\begin{array}{l}-0.00758 \\
(0.141)\end{array}$ & $\begin{array}{l}-0.0804 \\
(0.112)\end{array}$ & $\begin{array}{l}-0.0322 \\
(0.0840)\end{array}$ \\
\hline Age-group 35-39 & $\begin{array}{l}-0.109 \\
(0.0918)\end{array}$ & $\begin{array}{c}-0.280^{*} \\
(0.156)\end{array}$ & $\begin{array}{r}-0.0697 \\
(0.115)\end{array}$ & $\begin{array}{c}-0.0791 \\
(0.0882)\end{array}$ \\
\hline Age-group 40-44 & -0.00386 & -0.160 & 0.00977 & 0.0532 \\
\hline Age-group 45-49 & $\begin{array}{l}-0.0252 \\
(0.0962)\end{array}$ & $\begin{array}{l}-0.00907 \\
(0.156)\end{array}$ & $\begin{array}{l}0.0397 \\
(0.120)\end{array}$ & $\begin{array}{l}0.0423 \\
(0.0931)\end{array}$ \\
\hline Age-group 50-54 & $\begin{array}{l}0.0264 \\
(0.0997)\end{array}$ & $\begin{array}{l}0.0645 \\
(0.160)\end{array}$ & $\begin{array}{l}0.0347 \\
(0.126)\end{array}$ & $\begin{array}{l}0.0610 \\
(0.0961)\end{array}$ \\
\hline Age-group 55-60 & $\begin{array}{l}0.528^{* * *} \\
(0.0986)\end{array}$ & $\begin{array}{l}0.471 * * * \\
(0.157)\end{array}$ & $\begin{array}{l}0.483^{* * *} \\
(0.122)\end{array}$ & $\begin{array}{l}0.480^{* * *} \\
(0.0961)\end{array}$ \\
\hline Years of education (Std) & $\begin{array}{l}-0.0864 * * * \\
(0.0215)\end{array}$ & $\begin{array}{c}-0.0609^{*} \\
(0.0356)\end{array}$ & $\begin{array}{l}-0.201 * * * \\
(0.0307)\end{array}$ & $\begin{array}{l}-0.0743^{* * *} \\
(0.0212)\end{array}$ \\
\hline Willingness to take risks (Std) & $\begin{array}{l}-0.0500^{* *} \\
(0.0209)\end{array}$ & $\begin{array}{l}-0.0946^{* * *} \\
(0.0357)\end{array}$ & $\begin{array}{l}-0.0218 \\
(0.0252)\end{array}$ & $\begin{array}{l}-0.0502 * * \\
(0.0204)\end{array}$ \\
\hline Being pessimistic (Std) & $\begin{array}{l}0.0796 * * * \\
(0.0222)\end{array}$ & $\begin{array}{l}0.0108 \\
(0.0332)\end{array}$ & $\begin{array}{l}0.154 * * * \\
(0.0270)\end{array}$ & $\begin{array}{l}0.0643 * * * \\
(0.0220)\end{array}$ \\
\hline Being conscientious ( $\mathrm{Std}$ ) & $\begin{array}{l}-0.0843^{* * *} \\
(0.0202)\end{array}$ & $\begin{array}{l}-0.133^{* * * *} \\
(0.0289)\end{array}$ & $\begin{array}{c}-0.0492^{*} \\
(0.0259)\end{array}$ & $\begin{array}{l}-0.0815^{* * *} \\
(0.0197)\end{array}$ \\
\hline Being extraverted (Std) & $\begin{array}{l}0.0200 \\
(0.0199)\end{array}$ & $\begin{array}{l}0.0537 * \\
(0.0302)\end{array}$ & $\begin{array}{l}-0.000373 \\
(0.0250)\end{array}$ & $\begin{array}{l}0.00925 \\
(0.0200)\end{array}$ \\
\hline Being agreeable (Std) & $\begin{array}{l}0.0193 \\
(0.0189)\end{array}$ & $\begin{array}{l}0.0354 \\
(0.0296)\end{array}$ & $\begin{array}{l}0.0438^{*} \\
(0.0225)\end{array}$ & $\begin{array}{l}0.0348^{*} \\
(0.0185)\end{array}$ \\
\hline Being open to experience (Std) & $\begin{array}{l}0.0253 \\
(0.0209)\end{array}$ & $\begin{array}{l}0.0736 * * \\
(0.0329)\end{array}$ & $\begin{array}{l}-0.0291 \\
(0.0263)\end{array}$ & $\begin{array}{l}0.0198 \\
(0.0209)\end{array}$ \\
\hline Being neurotic (Std) & $\begin{array}{l}0.0668^{* * *} \\
(0.0191)\end{array}$ & $\begin{array}{l}0.100 * * * \\
(0.0277)\end{array}$ & $\begin{array}{l}0.0402 * \\
(0.0231)\end{array}$ & $\begin{array}{l}0.0466^{* *} \\
(0.0189)\end{array}$ \\
\hline Cognitive test score (Std) & $\begin{array}{l}-0.0154 \\
(0.0253)\end{array}$ & $\begin{array}{l}-0.0643^{* *} \\
(0.0313)\end{array}$ & $\begin{array}{l}0.0472 \\
(0.0314)\end{array}$ & $\begin{array}{l}-0.0159 \\
(0.0245)\end{array}$ \\
\hline Flag $(0,1)$ : Test score missing & $\begin{array}{l}-0.115 \\
(0.0817)\end{array}$ & $\begin{array}{l}-0.346 * * * \\
(0.0992)\end{array}$ & $\begin{array}{l}0.0468 \\
(0.105)\end{array}$ & $\begin{array}{l}-0.150^{*} \\
(0.0802)\end{array}$ \\
\hline Accumulated parttime experience & $\begin{array}{l}0.00514 \\
(0.0134)\end{array}$ & $\begin{array}{l}0.0118 \\
(0.0151)\end{array}$ & $\begin{array}{l}0.0983^{* * *} \\
(0.0124)\end{array}$ & $\begin{array}{l}0.00826 \\
(0.0159)\end{array}$ \\
\hline Hourly wage in t-2 (In) & $\begin{array}{l}-0.342 * * * \\
(0.0420)\end{array}$ & $\begin{array}{l}-0.0484 \\
(0.0620)\end{array}$ & $\begin{array}{l}-0.218^{* * *} \\
(0.0455)\end{array}$ & $\begin{array}{l}-0.309 * * * \\
(0.0437)\end{array}$ \\
\hline Years of tenure in $\mathrm{t}-2$ & $\begin{array}{l}-0.0576^{* * *} \\
(0.00555)\end{array}$ & $\begin{array}{l}-0.0452 * * * \\
(0.00834)\end{array}$ & $\begin{array}{l}-0.0638^{* * *} \\
(0.00703)\end{array}$ & $\begin{array}{l}-0.0468^{* * * *} \\
(0.00534)\end{array}$ \\
\hline Years of tenure squared in $\mathrm{t}-2$ & $\begin{array}{l}0.00150^{* * *} \\
(0.000159)\end{array}$ & $\begin{array}{l}0.00115 * * * \\
(0.000219)\end{array}$ & $\begin{array}{l}0.00158^{* * *} \\
(0.000195)\end{array}$ & $\begin{array}{l}0.00122 * * * \\
(0.000153)\end{array}$ \\
\hline Firm size up to 20 employees in $t-2$ & $\begin{array}{l}0.174 * * * \\
(0.0425)\end{array}$ & $\begin{array}{l}0.155^{* *} \\
(0.0649)\end{array}$ & $\begin{array}{l}0.0501 \\
(0.0502)\end{array}$ & $\begin{array}{l}0.170^{* * *} \\
(0.0416)\end{array}$ \\
\hline Firm size $201-2000$ employees in $\mathrm{t}-2$ & $\begin{array}{l}-0.121 * * * \\
(0.0463)\end{array}$ & $\begin{array}{c}-0.168^{* *} \\
(0.0754)\end{array}$ & $\begin{array}{c}-0.119^{* * *} \\
(0.0598)\end{array}$ & $\begin{array}{l}0.0203 \\
(0.0452)\end{array}$ \\
\hline Firm size 2001 to 20000 employees in t-2 & $\begin{array}{l}-0.0730 \\
(0.0483)\end{array}$ & $\begin{array}{l}0.0996 \\
(0.0721)\end{array}$ & $\begin{array}{l}-0.168 * * * \\
(0.0644)\end{array}$ & $\begin{array}{l}0.0523 \\
(0.0467)\end{array}$ \\
\hline Self-employed in $t-2$ & $\begin{array}{l}0.282 * * * \\
(0.0866)\end{array}$ & $\begin{array}{l}0.109 \\
(0.132)\end{array}$ & $\begin{array}{l}-0.478^{* * *} \\
(0.136)\end{array}$ & $\begin{array}{l}0.185^{* *} \\
(0.0857)\end{array}$ \\
\hline Married $(0,1)$ & $-0.157 * * *$ & -0.0686 & $-0.193 * * *$ & $-0.127 * * *$ \\
\hline Foreigner $(0,1)$ & $\begin{array}{l}0.202 * * * \\
(0.0597)\end{array}$ & $\begin{array}{l}0.0154 \\
(0.0921)\end{array}$ & $\begin{array}{l}0.307 * * * \\
(0.0747)\end{array}$ & $\begin{array}{l}0.263^{* * *} \\
(0.0586)\end{array}$ \\
\hline Unemployment rate by state and year (Std) & 0.0925 & -0.0582 & $0.214 * *$ & $0.123^{* *}$ \\
\hline Schlholst (Base: NRW)) & $\begin{array}{l}0.0305 \\
(0.125)\end{array}$ & $\begin{array}{l}-0.134 \\
(0.254)\end{array}$ & $\begin{array}{l}0.184 \\
(0.150)\end{array}$ & $\begin{array}{l}-0.0726 \\
(0.129)\end{array}$ \\
\hline Hamburg & $\begin{array}{l}0.159 \\
(0.164)\end{array}$ & $\begin{array}{l}0.102 \\
(0.260)\end{array}$ & $\begin{array}{l}0.244 \\
(0.180)\end{array}$ & $\begin{array}{l}0.133 \\
(0.169)\end{array}$ \\
\hline Lowsax & $\begin{array}{l}0.145^{* *} \\
(0.0673)\end{array}$ & $\begin{array}{l}0.244 * * \\
(0.106)\end{array}$ & $\begin{array}{l}-0.0239 \\
(0.0912)\end{array}$ & $\begin{array}{l}0.148 * * \\
(0.0681)\end{array}$ \\
\hline Bremen & $\begin{array}{l}-0.169 \\
(0.244)\end{array}$ & & 0.113 & 0.00457 \\
\hline Hessia & $\begin{array}{l}0.121 \\
(0.0802)\end{array}$ & $\begin{array}{l}0.0938 \\
(0.130)\end{array}$ & $\begin{array}{l}0.0835 \\
(0.117)\end{array}$ & $\begin{array}{l}0.0502 \\
(0.0774)\end{array}$ \\
\hline Rhineland & $\begin{array}{l}0.196 * * \\
(0.0892)\end{array}$ & $\begin{array}{l}0.0655 \\
(0.133)\end{array}$ & $\begin{array}{l}0.257 * * \\
(0.106)\end{array}$ & $\begin{array}{l}0.133 \\
(0.0876)\end{array}$ \\
\hline Badenwuert & $\begin{array}{l}-0.115 \\
(0.0777)\end{array}$ & $\begin{array}{l}0.0235 \\
(0.116)\end{array}$ & $\begin{array}{l}-0.119 \\
(0.102)\end{array}$ & $\begin{array}{l}0.0361 \\
(0.0742)\end{array}$ \\
\hline Bavaria & $\begin{array}{l}0.0396 \\
(0.0720)\end{array}$ & $\begin{array}{l}0.158 \\
(0.105)\end{array}$ & $\begin{array}{l}0.0363 \\
(0.0947)\end{array}$ & $\begin{array}{l}0.0756 \\
(0.0679)\end{array}$ \\
\hline Saarland & $\begin{array}{l}-0.191 \\
(0.202)\end{array}$ & $\begin{array}{l}0.303 \\
(0.222)\end{array}$ & $\begin{array}{l}-0.141 \\
(0.252)\end{array}$ & $\begin{array}{l}-0.0302 \\
(0.251)\end{array}$ \\
\hline Berlin & -0.0446 & 0.354 & -0.163 & -0.146 \\
\hline Brandenb & $\begin{array}{l}0.0409 \\
(0.128)\end{array}$ & $\begin{array}{l}0.305 \\
(0.210)\end{array}$ & $\begin{array}{r}-0.0368 \\
(0.173)\end{array}$ & $\begin{array}{l}-0.0471 \\
(0.120)\end{array}$ \\
\hline Mecklenb & $\begin{array}{c}-0.0673 \\
(0.167)\end{array}$ & $\begin{array}{l}0.335 \\
(0.256)\end{array}$ & $\begin{array}{r}-0.0755 \\
(0.211)\end{array}$ & $\begin{array}{l}-0.218 \\
(0.157)\end{array}$ \\
\hline Saxony & $\begin{array}{l}-0.145 \\
(0.126)\end{array}$ & $\begin{array}{l}0.151 \\
(0.211)\end{array}$ & $\begin{array}{l}-0.112 \\
(0.168)\end{array}$ & $\begin{array}{l}-0.237^{*} \\
(0.121)\end{array}$ \\
\hline Saxanh & -0.121 & 0.157 & -0.200 & $-0.261^{*}$ \\
\hline Thuring & $(0.156)$ & $(0.270)$ & (0.213) & $(0.147)$ \\
\hline Thuring & $\begin{array}{l}-0.101 \\
(0.121)\end{array}$ & $\begin{array}{l}0.302 \\
(0.184)\end{array}$ & $\begin{array}{r}-0.0591 \\
(0.152)\end{array}$ & $\begin{array}{l}-0.219^{*} \\
(0.117)\end{array}$ \\
\hline Constant & $\begin{array}{c}-0.0433 \\
(0.152)\end{array}$ & $\begin{array}{l}-1.719^{* * *} \\
(0.225)\end{array}$ & $\begin{array}{l}-0.897^{* * *} \\
(0.185)\end{array}$ & $\begin{array}{l}-0.124 \\
(0.153)\end{array}$ \\
\hline
\end{tabular}

Marginal effects are obtained using the margins command in STATA. Marginal effects for interaction effects are calculated according to Karaca-Mandic et al. (2012). Standard errors are clustered over individual identifiers to account for repeat observations. The sample is conditioned on being full-time employed (working 37 hours or more) in $t-2$. Omitted are year-fixed effects, industry-, and occupation 


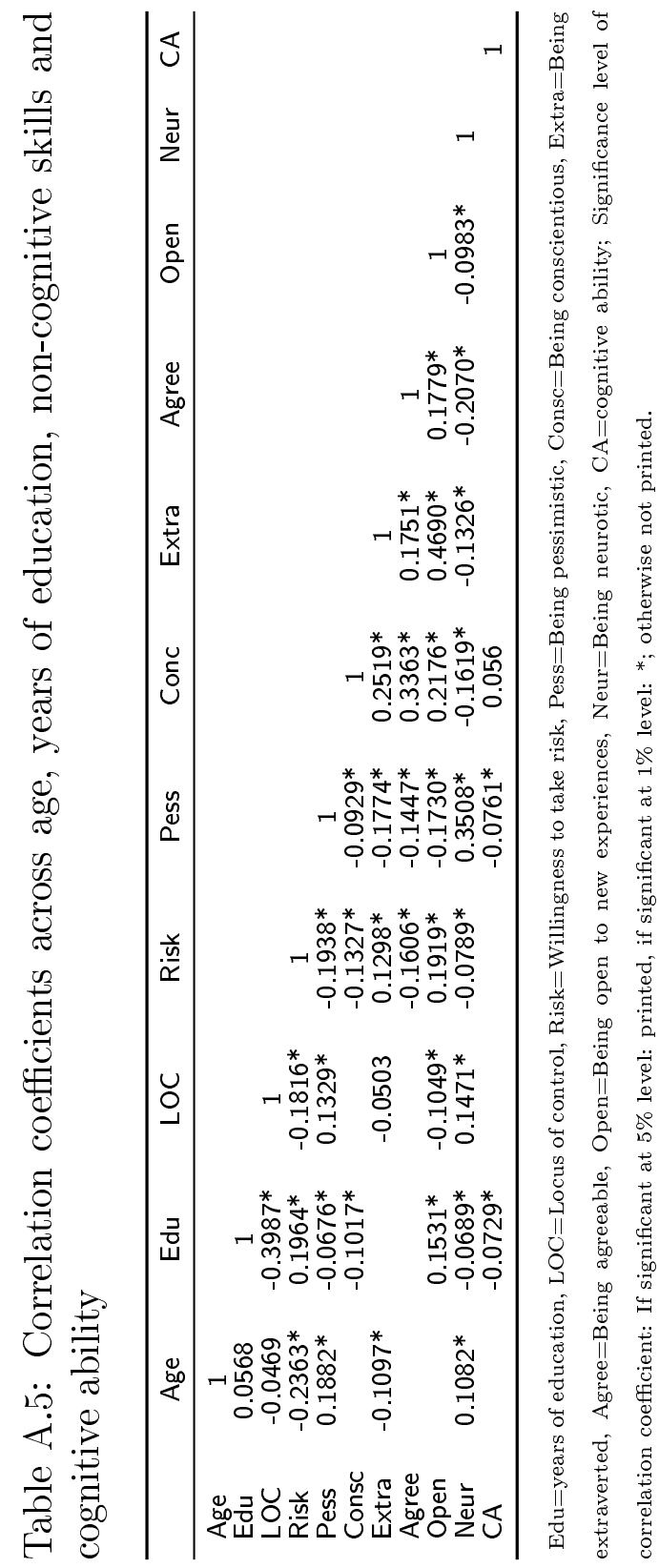

